\title{
Integration of Entomopathogenic Fungi into IPM Programs: Studies Involving Weevils (Coleoptera: Curculionoidea) Affecting Horticultural Crops
}

\author{
Kim Khuy Khun ${ }^{1,2, *(\mathbb{D} \text {, Bree A. L. Wilson }}{ }^{2}$, Mark M. Stevens ${ }^{3,4}$, Ruth K. Huwer ${ }^{5}$ and \\ Gavin J. Ash ${ }^{2}$ (D) \\ 1 Faculty of Agronomy, Royal University of Agriculture, P.O. Box 2696, Dangkor District, \\ Phnom Penh, Cambodia \\ 2 Centre for Crop Health, Institute for Life Sciences and the Environment, University of Southern Queensland, \\ Toowoomba, Queensland 4350, Australia; bree.wilson@usq.edu.au (B.A.L.W.); gavin.ash@usq.edu.au (G.J.A.) \\ 3 NSW Department of Primary Industries, Yanco Agricultural Institute, Yanco, New South Wales 2703, \\ Australia; mark.stevens@dpi.nsw.gov.au \\ 4 Graham Centre for Agricultural Innovation (NSW Department of Primary Industries and Charles Sturt \\ University), Wagga Wagga, New South Wales 2650, Australia \\ 5 NSW Department of Primary Industries, Wollongbar Primary Industries Institute, \\ Wollongbar, New South Wales 2477, Australia; ruth.huwer@dpi.nsw.gov.au \\ * Correspondence: kimkhuy.khun@usq.edu.au or khun.kimkhuy@rua.edu.kh; Tel.: +61-46-9731208
}

Received: 7 September 2020; Accepted: 21 September 2020; Published: 25 September 2020

Simple Summary: Horticultural crops are vulnerable to attack by many different weevil species. Fungal entomopathogens provide an attractive alternative to synthetic insecticides for weevil control because they pose a lesser risk to human health and the environment. This review summarises the available data on the performance of these entomopathogens when used against weevils in horticultural crops. We integrate these data with information on weevil biology, grouping species based on how their developmental stages utilise habitats in or on their hostplants, or in the soil. These patterns of habitat usage can help identify the stages during which pest species are at their most vulnerable, and also help to determine the most effective ways to deploy entomopathogens for their control.

\begin{abstract}
Weevils are significant pests of horticultural crops and are largely managed with insecticides. In response to concerns about negative impacts of synthetic insecticides on humans and the environment, entomopathogenic fungi (EPF) have been developed as an alternative method of control, and as such appear to be "ready-made" components of integrated pest management (IPM) programs. As the success of pest control requires a thorough knowledge of the biology of the pests, this review summarises our current knowledge of weevil biology on nut trees, fruit crops, plant storage roots, and palm trees. In addition, three groups of life cycles are defined based on weevil developmental habitats, and together with information from studies of EPF activity on these groups, we discuss the tactics for integrating EPF into IPM programs. Finally, we highlight the gaps in the research required to optimise the performance of EPF and provide recommendations for the improvement of EPF efficacy for the management of key weevils of horticultural crops.
\end{abstract}

Keywords: attract-and-kill; Bacillus thuringiensis; Beauveria; endophyte; entomopathogenic nematode; Metarhizium; repellent volatile; sterile male; transmission; weevil 


\section{Introduction}

Insect pests are one of the main constraints to global crop production and reduce crop yields by $30-40 \%$, equating to US $\$ 300$ to 470 billion worth of production losses each year [1,2]. To manage them, synthetic insecticides are routinely used by commercial growers, with at least US\$16 to 20 billion being spent on insecticides annually [1,3]. However, a sole reliance on insecticides is not considered sustainable as they are often harmful to endemic natural enemies within crops and may induce insecticide resistance in the target pest [4]. The same insecticides may also increase the frequency of primary and secondary pest outbreaks [5]. For example, pecan scab (Venturia effusa), pecan weevil (Curculio caryae) and pentatomid stink bugs (Nezara viridula and Euschistus sp.) are the key problems in pecan (Carya illinoinensis) plantations and to minimise their impact, preventive applications of broad-spectrum pesticides are used. Pyrethroids and carbaryl are used for control of late-season pecan weevil and kernel-feeding hemipterans; however, these insecticides also destroy aphidophagous insects and repel or kill predatory mites. Consequently, aphid and phytophagous mite resurgences are often observed [6]. Fungicides can also contribute to pest outbreaks and resurgence as a consequence of their impact on entomopathogenic fungi (EPF) $[6,7]$. The fungicides applied to control pecan scab are reported to kill the EPF that provide control of pecan aphids [8] and as a consequence, secondary outbreaks of aphids require additional application of insecticides [6].

Microbial biopesticides have been recognised as alternatives to synthetic insecticides, since they can have minimal impacts on non-target organisms, prevent pesticide resistance, and are less toxic to both humans and the environment $[9,10]$. On a global scale, microbial biopesticides account for approximately US $\$ 3.3$ billion or around $8 \%$ of all pesticides sold [11], but they have long-term potential for increased usage over the next few decades [12]. Among the microbial biopesticides, EPF are the second-highest selling, accounting for around $9 \%$ of all microbial biopesticides sold globally [11]. Their popularity stems from their potential to control a wide range of insect pests $[13,14]$ and their suitability for organic and sustainable crop production [15]. In addition to their direct impact on insect pests, EPF have also been reported to act as endophytes within host plants [16], can be integrated with attractants for attract-and-kill pest management approaches $[17,18]$, and can be combined with sterile males for integration with the Sterile Insect Technique (SIT) [19-21]. Entomopathogenic fungi may also have synergistic interactions with some beneficial arthropods (predators, parasitoids, pollinators) [22-24], other entomopathogens (bacteria and nematodes) [25,26] and synthetic insecticides $[27,28]$ that could be exploited within IPM programs on various crops.

Weevils are amongst the most important pests of horticultural crops. They often have behaviours and habitats that can make some insecticides difficult to deploy. For example, pecan weevil is a major pest of pecans in the southern United States [29] where the damage caused by larvae and adults can reduce yields by up to $80 \%$ [30]. This weevil has a lengthy and complicated life cycle $(90 \%$ of the population complete their life cycle in 2 years while $10 \%$ take up to 3 years) with the larvae and pupae occurring inside nuts and in the soil, respectively [29]. This makes the opportunities to control this weevil using contact insecticides limited to only the adults.

Another important weevil in horticulture is the coffee berry borer (Hypothenemus hampei). It is a major pest of coffee (Coffea arabica and C. canephora) worldwide [31], with the damage caused by the larvae and adults estimated to cost the industry around US\$500 million annually [32]. This borer is also difficult to control as the larval and pupal stages only occur inside the coffee berries [31]. There are many other weevil species in which one or more developmental stages live within the host plant and/or the soil and cause significant damage to horticultural crops (Table 1).

\section{Methodology}

This review describes the potential use of EPF (particularly Beauveria spp. and Metarhizium spp.) alone or in combination with other management techniques to control weevils in horticultural crops. Studies using Metarhizium spp. or Beauveria spp. for managing weevils affecting horticultural crops were identified using databases including Web of Science (http://www.webofknowledge.com), 
SCOPUS (https://www.scopus.com), CAB Abstracts (https://www.cabdirect.org) and Google Scholar (https://scholar.google.com). A total of 1666 articles (Figure S1) were identified from searches using the terms "Metarhizium", "Beauveria", "Weevil", and "Curculionidae". After removing duplicates, 566 article titles were screened and 391 were excluded from this review because they fell outside the scope of this review due to the host crop involved, or other factors. The final 175 full-text articles, which show a strong bias towards perrenial crops, are included in this review. Fourty-four weevil species were identified as having a major impact on horticultural crops (Table 1). Studies published between 1973 and 2020 that dealt with the use of EPF for weevil control involved 26 of these species, and of these, data on life cycle duration was available for 21 (Table 2, Figure S2). The 26 weevil species used in experiments involving EPF could be grouped according to their patterns of habitat utilisation throughout their life cycles (Figure 1, Table 3). Successful pest management requires a thorough knowledge of pest biology [33], and in this review we combine published data with these patterns of habitat utilisation to identify the optimal approaches for integrating EPF into weevil IPM programs, targeting the most vulnerable developmental stages for each weevil group.

In this review, weevils are defined as the superfamily Curculionoidea, following the taxonomy of Oberprieler et al. [34] where the Curculioninae, Cyclominae, Dryophthorinae, Entiminae, Molytinae, and Scolytinae have subfamily status within the Curculionidae, and the Brentinae are a subfamily within the Brentidae. 
Table 1. Important weevil species of horticultural crops, including crops impacted, geographical distribution and economic impact.

\begin{tabular}{|c|c|c|c|c|c|c|c|}
\hline Weevil Species & Common Name & $\begin{array}{c}\text { Family: } \\
\text { Subfamily }{ }^{1}\end{array}$ & Distribution $^{2}$ & Crops & Damaging Stages $^{3}$ & Economic Impact ${ }^{4}$ & Ref. \\
\hline Aclees sp. cf. foveatus (Voss) & Fig weevil & Cur: Mol & IT & Fig & A \& L & $\mathrm{n} / \mathrm{a}$ & [35] \\
\hline Aegorhinus superciliosus (Guérin) & Raspberry weevil & Cur: Cyc & $\mathrm{AR} \& \mathrm{CL}$ & $\begin{array}{l}\text { Blueberries, } \\
\text { raspberries, } \\
\text { strawberry }\end{array}$ & A \& L & $\mathrm{n} / \mathrm{a}$ & {$[36,37]$} \\
\hline Anthonomus musculus (Say) & Cranberry weevil & Cur: Cur & $\begin{array}{c}\text { North-Eastern US \& } \\
\text { CA }\end{array}$ & $\begin{array}{l}\text { Blueberries, } \\
\text { cranberries }\end{array}$ & A \& L & $\mathrm{n} / \mathrm{a}$ & [38] \\
\hline Anthonomus piri (Kollar) & Apple bud weevil & Cur: Cur & EUR \& GB & Apple, pears & A \& L & $\mathrm{n} / \mathrm{a}$ & [39] \\
\hline Anthonomus pomorum (L.) & Apple blossom weevil & Cur: Cur & EUR & Apple, pears & A \& L & $\mathrm{n} / \mathrm{a}$ & [39] \\
\hline Anthonomus rubi (Herbst) & $\begin{array}{c}\text { Strawberry blossom } \\
\text { weevil }\end{array}$ & Cur: Cur & EUR \& GB & $\begin{array}{l}\text { Strawberry, blackberry, } \\
\text { raspberry }\end{array}$ & A \& L & MCL between 36-90\% & {$[40,41]$} \\
\hline Anthonomus signatus (Say) & Strawberry bud weevil & Cur: Cur & US \& CA & Strawberry & A \& L & $\begin{array}{l}\text { MCL up to } 100 \% \text { in New York } \\
\& 70 \% \text { in Quebec }\end{array}$ & [42] \\
\hline Blosyrus asellus (Olivier) & $\begin{array}{l}\text { Rough sweetpotato } \\
\text { weevil }\end{array}$ & Cur: Ent & US & Sweetpotato & A \& L & $\mathrm{n} / \mathrm{a}$ & [43] \\
\hline Conotrachelus nenuphar (Herbst) & Plum curculio & Cur: Mol & $\begin{array}{l}\text { Eastern \& central } \\
\text { NAM (US, CA) }\end{array}$ & Pome \& stone fruits & A \& L & $\begin{array}{l}\text { MCL up to } 85 \% \text { in unsprayed } \\
\text { orchard }\end{array}$ & {$[44,45]$} \\
\hline Conotrachelus psidii (Marshall) & Guava weevil & Cur: Mol & $\begin{array}{c}\mathrm{BO}, \mathrm{BR}, \mathrm{CO}, \mathrm{MX}, \mathrm{PY} \\
\& \mathrm{VE}\end{array}$ & Guava & $\mathrm{L}$ & $\begin{array}{l}\text { MCL up to } 100 \% \text { in Rio de } \\
\text { Janeiro, Brazil }\end{array}$ & {$[46,47]$} \\
\hline Cosmopolites sordidus (Germar) & Banana weevil & Cur: Dry & $\begin{array}{l}\text { Tropical regions } \\
\text { worldwide }\end{array}$ & Banana \& plantain & A \& L & MCL up to $50 \%$ & {$[31,48]$} \\
\hline Curculio caryae (Horn) & Pecan weevil & Cur: Cur & Southern US & Pecan & A \& L & MCL between $30-80 \%$ & {$[29,30]$} \\
\hline Curculio caryatrypes (Boheman) & Larger chestnut weevil & Cur: Cur & Central-eastern US & Chestnut & A \& L & $\mathrm{n} / \mathrm{a}$ & [49] \\
\hline Curculio elephas (Gyllenhal) & Chestnut weevil & Cur: Cur & $\begin{array}{c}\text { Central \& Southern } \\
\text { EUR, North AFR }\end{array}$ & Chestnut & A \& L & MCL up to $90 \%$ in Italy & {$[39,50]$} \\
\hline Curculio писит (L.) & Hazelnut weevil & Cur: Cur & $\begin{array}{l}\text { PAL, also present in } \\
\text { North AFR }\end{array}$ & Hazelnut & A \& L & $\begin{array}{l}\text { MCL up to } 80 \% \text { in the } \\
\text { unprotected orchards in Spain }\end{array}$ & {$[51,52]$} \\
\hline Curculio sayi (Gyllenhal) & Lesser chestnut weevil & Cur: Cur & Central-eastern US & Chestnut & A \& L & $\mathrm{n} / \mathrm{a}$ & [49] \\
\hline Curculio sikkimensis (Heller) & Chestnut weevil & Cur: Cur & $\mathrm{CN}, \mathrm{IN}, \mathrm{JP} \& \mathrm{KR}$ & Chestnut & A \& L & $\mathrm{n} / \mathrm{a}$ & {$[53,54]$} \\
\hline Cylas formicarius (F.) & Sweetpotato weevil & Bre: Bre & $\begin{array}{l}\text { Tropical regions } \\
\text { worldwide }\end{array}$ & Sweetpotato & A \& L & MCL up to $100 \%$ & {$[31,55]$} \\
\hline
\end{tabular}


Table 1. Cont.

\begin{tabular}{|c|c|c|c|c|c|c|c|}
\hline Weevil Species & Common Name & $\begin{array}{c}\text { Family: } \\
\text { Subfamily }{ }^{1}\end{array}$ & Distribution $^{2}$ & Crops & Damaging Stages $^{3}$ & Economic Impact ${ }^{4}$ & Ref. \\
\hline $\begin{array}{c}\text { Cylas puncticollis (Boheman), } \\
\text { C. brunneus (F.) }\end{array}$ & $\begin{array}{c}\text { African sweetpotato } \\
\text { weevil }\end{array}$ & Bre: Bre & AFR (sub-Saharan) & Sweetpotato & A \& L & MCL up to $97 \%$ & {$[55,56]$} \\
\hline Diaprepes abbreviatus (L.) & Citrus root weevil & Cur: Ent & US \& several CAR & Citrus, sugarcane & $\mathrm{L}$ & $\mathrm{n} / \mathrm{a}$ & [57] \\
\hline Heilipus lauri (Boheman) & Avocado seed weevil & Cur: Mol & $\mathrm{CO} \& \mathrm{MX}$ & Avocado & A \& L & $\begin{array}{l}\text { MCL between } 60-70 \% \text { in } \\
\text { Mexico }\end{array}$ & {$[58,59]$} \\
\hline Hypotheneтиs hampei (Ferrari) & Coffee berry borer & Cur: Sco & $\begin{array}{c}\text { AFR, ASI, OCE, SCA } \\
\text { \& US }\end{array}$ & Coffee & A \& L & $\begin{array}{l}\text { MCL between } 40-90 \% \text {. EAL } \\
\text { around US } \$ 215-358 \text { million in } \\
\text { Brazil or around US } \$ 500 \\
\text { million worldwide }\end{array}$ & {$[31,32,60]$} \\
\hline $\begin{array}{l}\text { Kuschelorhynchus macadamiae } \\
\text { (Jennings \& Oberprieler) }\end{array}$ & Macadamia seed weevil & Cur: Cur & Eastern AU & Macadamia & A \& L & MCL up to $15 \%$ & {$[61,62]$} \\
\hline Odoiporus longicollis (Olivier) & Banana stem weevil & Cur: Dry & Tropical ASI & Banana \& plantain & A \& L & MCL between $10-90 \%$ & [63] \\
\hline Otiorhynchus clavipes (Bonsdorff) & Red-legged weevil & Cur: Ent & Western EUR & $\begin{array}{l}\text { Plum, apple, berry } \\
\text { crops, grapevine }\end{array}$ & $A \& L$ & $\mathrm{n} / \mathrm{a}$ & [39] \\
\hline Otiorhynchus ovatus (L.) & Strawberry weevil & Cur: Ent & EUR \& NAM & $\begin{array}{l}\text { Strawberry, berry } \\
\text { crops }\end{array}$ & $A \& L$ & $\begin{array}{l}\text { MCL up to } 100 \% \text { in Saxony, } \\
\text { Germany }\end{array}$ & [39] \\
\hline Otiorhynchus rugifrons (Gyllenhal) & Strawberry root weevil & Cur: Ent & EUR & Strawberry & A \& L & $\mathrm{n} / \mathrm{a}$ & [39] \\
\hline $\begin{array}{l}\text { Otiorhynchus rugosostriatus } \\
\text { (Goeze) }\end{array}$ & $\begin{array}{c}\text { Rough strawberry root } \\
\text { weevil }\end{array}$ & Cur: Ent & EUR, NAM \& MED & $\begin{array}{l}\text { Strawberry, berry } \\
\text { crops }\end{array}$ & A \& L & $\mathrm{n} / \mathrm{a}$ & [39] \\
\hline Otiorhynchus singularis (L.) & Clay-coloured weevil & Cur: Ent & EUR \& NAM & $\begin{array}{l}\text { Apple, pear, berry } \\
\text { crops, grapevine }\end{array}$ & $A \& L$ & $\mathrm{n} / \mathrm{a}$ & [39] \\
\hline Otiorhynchus sulcatus (F.) & Black vine weevil & Cur: Ent & EUR, NAM \& AUA & $\begin{array}{l}\text { Grapevines, berry } \\
\text { crops }\end{array}$ & A \& L & $\mathrm{n} / \mathrm{a}$ & {$[39,64]$} \\
\hline Pantorhytes plutus (Oberthür) & Cacao weevil & Cur: Ent & PG & Cacao & $\mathrm{L}$ & $\mathrm{n} / \mathrm{a}$ & {$[65,66]$} \\
\hline Phlyctinus callosus (Schönherr) & Banded fruit weevil & Cur: Ent & $\mathrm{AU}, \mathrm{NZ} \& \mathrm{ZA}$ & $\begin{array}{l}\text { Grapevines, pome } \\
\text { fruit, stone fruits }\end{array}$ & $A \& L$ & MCL up to $40 \%$ & {$[67,68]$} \\
\hline $\begin{array}{l}\text { Pityophthorus juglandis } \\
\text { (Blackman) }\end{array}$ & Walnut twig beetle & Cur: Sco & $\begin{array}{c}\text { south-western US \& } \\
\text { MX } \\
\end{array}$ & Walnut & A \& L & $\mathrm{n} / \mathrm{a}$ & [69] \\
\hline $\begin{array}{l}\text { Rhynchophorus bilineatus } \\
\text { (Montrouzier) }\end{array}$ & Black palm weevil & Cur: Dry & ID, PG \& SB & Palm & $\mathrm{L}$ & $\mathrm{n} / \mathrm{a}$ & [70] \\
\hline Rhynchophorus cruentatus (F.) & Palmetto weevil & Cur: Dry & $\begin{array}{c}\text { Florida \& } \\
\text { south-eastern US }\end{array}$ & Palm & $\mathrm{L}$ & $\mathrm{n} / \mathrm{a}$ & [70] \\
\hline $\begin{array}{c}\text { Rhynchophorus ferrugineus } \\
\text { (Olivier) }\end{array}$ & Red palm weevil & Cur: Dry & ASI, AU \& MED & Palm & $\mathrm{L}$ & $\begin{array}{l}\text { EAL around US\$5-26 million } \\
\text { in the Middle East }\end{array}$ & {$[71,72]$} \\
\hline
\end{tabular}


Table 1. Cont.

\begin{tabular}{|c|c|c|c|c|c|c|c|}
\hline Weevil Species & Common Name & $\begin{array}{c}\text { Family: } \\
\text { Subfamily }{ }^{1}\end{array}$ & Distribution $^{2}$ & Crops & Damaging Stages $^{3}$ & Economic Impact ${ }^{4}$ & Ref. \\
\hline Rhynchophorus palmarum (L.) & American palm weevil & Cur: Dry & MX \& SCA & Palm & $\mathrm{L}$ & MCL up to $15 \%$ & {$[70,73]$} \\
\hline Rhynchophorus phoenicis (F.) & African palm weevil & Cur: Dry & AFR & Palm & $\mathrm{L}$ & $\mathrm{n} / \mathrm{a}$ & [70] \\
\hline $\begin{array}{l}\text { Rhynchophorus quadrangulus } \\
\text { (Queden) }\end{array}$ & $\mathrm{n} / \mathrm{a}$ & Cur: Dry & AFR & Palm & $\mathrm{L}$ & $\mathrm{n} / \mathrm{a}$ & [70] \\
\hline $\begin{array}{l}\text { Scolytus amygdali } \\
\text { (Guérin-Méneville) }\end{array}$ & Almond bark beetle & Cur: Sco & MED & $\begin{array}{l}\text { Almond, apricot, } \\
\text { peach }\end{array}$ & A \& L & $\mathrm{n} / \mathrm{a}$ & [39] \\
\hline $\begin{array}{l}\text { Scolytus mali (Bechstein \& } \\
\text { Scharfenberg) }\end{array}$ & Large fruit bark beetle & Cur: Sco & EUR \& PAL & Apple, plum, pear & A \& L & $\mathrm{n} / \mathrm{a}$ & [39] \\
\hline Scolytus rugulosus (Müller) & Fruit bark beetle & Cur: Sco & EUR & Apple, pear, plum & A \& L & $\mathrm{n} / \mathrm{a}$ & [39] \\
\hline Xyleborus affinis (Eichhoff) & Ambrosia beetle & Cur: Sco & MX \& US & $\begin{array}{l}\text { Avocado, mango, } \\
\text { macadamia, walnut }\end{array}$ & A \& L & $\mathrm{n} / \mathrm{a}$ & {$[74-76]$} \\
\hline
\end{tabular}

${ }^{1}$ Bre: Bre = Brentidae: Brentinae, Cur: Cur = Curculionidae: Curculioninae, Cur: Cyc = Curculionidae: Cyclominae, Cur: Dry = Curculionidae: Dryophthorinae, Cur: Ent $=$ Curculionidae: Entiminae, Cur: $\mathrm{Mol}=$ Curculionidae: Molytinae, Cur: Sco = Curculionidae: Scolytinae. ${ }^{2} \mathrm{AFR}=\mathrm{Africa}, \mathrm{AR}=\mathrm{Argentina}, \mathrm{ASI}=\mathrm{Asia}, \mathrm{AU}=\mathrm{Australia}, \mathrm{AUA}=\mathrm{Australasia}, \mathrm{BO}=\mathrm{Bolivia}$, $\mathrm{KR}=$ Korea $\mathrm{MED}=$ Mediterranean area, $\mathrm{MX}=$ Mexico, NAM = North America, NZ = New Zealand, $\mathrm{OCE}=$ Oceania, $\mathrm{PAL}=\mathrm{Palaearctic}, \mathrm{PG}=\mathrm{Papua}$ New $\mathrm{Guinea}, \mathrm{PY}=\mathrm{Paraguay}$, $\mathrm{SCA}=$ South and Central America, $\mathrm{SB}=$ Solomon Islands, US = United States, VE = Venezuela, ZA = South Africa (code follows https://www.iso.org $/$ ). ${ }^{3} \mathrm{~A}=\mathrm{adults}, \mathrm{L}=\mathrm{Larvae}$. ${ }^{4} \mathrm{n} / \mathrm{a}=$ Specific data not available, $\mathrm{MCL}=$ may cause yield or crop loss, $\mathrm{EAL}=$ estimated annual loss. Ref. = References. 
Table 2. Weevil life stage durations (where known) for important horticultural pest species used in experiments with EPF.

\begin{tabular}{|c|c|c|c|c|c|c|}
\hline Weevil Species & Egg (Days) & Larvae (Days) & Pupae (Days) & Adult (Days) & Generation & Ref. \\
\hline Aclees sp. cf. foveatus & $10-20$ & $\mathrm{n} / \mathrm{a}$ & $\mathrm{n} / \mathrm{a}$ & $\mathrm{n} / \mathrm{a}$ & 2 generations/year & [35] \\
\hline Anthonomus signatus & $6-14$ & $21-28$ & $5-8$ & $\mathrm{n} / \mathrm{a}$ & 32-64 days/generation, 1 generation/year & {$[42,77]$} \\
\hline Conotrachelus nenuphar & $2-12$ & $14-21$ & 30 & $\mathrm{n} / \mathrm{a}$ & 57 days/generation & {$[78]$} \\
\hline Conotrachelus psidii & $2-6$ & $8-27$ & $14-18$ & $<418$ & 108-280 days/generation & [79] \\
\hline Cosmopolites sordidus & $5-8$ & $14-21$ & $5-7$ & $<730$ & 1-6 months/generation & {$[31,80]$} \\
\hline Curculio caryae & $\mathrm{n} / \mathrm{a}$ & 30 & $270-1080$ & $\mathrm{n} / \mathrm{a}$ & $2-3$ years/generation & {$[29,81]$} \\
\hline Curculio elephas & $\mathrm{n} / \mathrm{a}$ & 730-1095 & $90-150$ & $\mathrm{n} / \mathrm{a}$ & 1 generation/year in Italy & {$[50,82]$} \\
\hline Curculio nuсum & $>7$ & $28-35$ & $<365$ & 90 & 1 generation/year in Turkey & {$[39,83]$} \\
\hline Cylas formicarius & $3-7$ & $7-11$ & $5-7$ & $<240$ & 5-8 generations/year in United States & {$[31,55]$} \\
\hline Cylas puncticollis & $<5$ & $<23$ & $<14$ & $<141$ & 20-25 days/generation & {$[56]$} \\
\hline Diaprepes abbreviatus & $7-10$ & $240-450$ & $15-30$ & $<147$ & 5-18 months/generation & [84] \\
\hline Heilipus lauri & $<13$ & $<49$ & $<15$ & $\mathrm{n} / \mathrm{a}$ & 76 days/generation & {$[58]$} \\
\hline Hypothenemus hampei & $5-9$ & $10-26$ & $4-9$ & $<157$ & $\begin{array}{l}\text { 25-35 days/generation, }>8 \text { generations/year in African } \\
\text { countries, } 2-3 \text { generations/year in Colombia }\end{array}$ & {$[31,85]$} \\
\hline Kuschelorhynchus macadamiae & 6 & 28 & 4 & $\mathrm{n} / \mathrm{a}$ & At least 3 generations/year & [86] \\
\hline Odoiporus longicollis & $3-8$ & $30-60$ & $17-22$ & $50-95$ & 53-95 days/generation & [87] \\
\hline Otiorhynchus sulcatus & $>8$ & $84-211$ & $10-50$ & $\mathrm{n} / \mathrm{a}$ & 1 generation/year & {$[64]$} \\
\hline Pantorhytes plutus & $\mathrm{n} / \mathrm{a}$ & $90-270$ & 14 & $365-730$ & 4-11 months/generation & {$[88]$} \\
\hline Phlyctinus callosus & $6-15$ & $\mathrm{n} / \mathrm{a}$ & $7-21$ & $\mathrm{n} / \mathrm{a}$ & 1-2 generations/year & [89] \\
\hline Pityophthorus juglandis & $\mathrm{n} / \mathrm{a}$ & $\mathrm{n} / \mathrm{a}$ & $\mathrm{n} / \mathrm{a}$ & $\mathrm{n} / \mathrm{a}$ & 7 weeks/generation, 2 generations/year & [90] \\
\hline Rhynchophorus ferrugineus & $1-6$ & 25-105 & $11-45$ & $\mathrm{n} / \mathrm{a}$ & $\begin{array}{c}45 \text { days/generation in the Philippines, } 139 \text { days/generation } \\
\text { in Spain; 3-4 generations/year in India, up to } 21 \\
\text { generations/year in Egypt }\end{array}$ & {$[71]$} \\
\hline Scolytus amygdali & $\mathrm{n} / \mathrm{a}$ & $\mathrm{n} / \mathrm{a}$ & $\mathrm{n} / \mathrm{a}$ & $\mathrm{n} / \mathrm{a}$ & $>3$ generations/year in the Mediterranean area & [91] \\
\hline
\end{tabular}

Note: Aegorhinus superciliosus, Blosyrus asellus, Curculio sikkimensis, Rhynchophorus bilineatus and Xyleborus affinis were not included in this table as specific data are not available. $\mathrm{n} / \mathrm{a}=$ specific data not available. Ref. = References 


\section{Life Cycle Patterns of Weevils Affecting Horticultural Crops}

The three patterns of weevil life cycles which occur in association with horticultural crops are summarised in Figure 1 and Table 3. Adult weevils are normally active on the host plant during feeding and mating. Three locations on or around the host plant are potentially suitable sites for weevils to lay eggs, depending on the species' biology; (1) in/on the fruit, berry or nut; (2) in/on the bud, leaf, branch, vine, stem, pseudostem, corm, or storage root and (3) in the soil or at the base of the plant. As larvae hatch from the eggs they move to, or are already positioned at the location of the larval food source; (1) in the bud, branch, stem, pseudostem, corm, storage root or root; (2) in the fruit, berry or nut. The larval and pupal habitats never leave the immature stages exposed where they could be directly sprayed with either entomopathogens or contact insecticides. The mature larvae pupate either (1) in the berry, nut, bud, branch, vine, stem, pseudostem, corm or storage root of the host plant, or (2) under the ground. Some species need to diapause or overwinter in the soil as either larvae (pecan weevil, chestnut weevil, hazelnut weevil, black vine weevil, banded fruit weevil) or adults (walnut twig beetle, strawberry bud weevil, macadamia seed weevil, chestnut weevil, hazelnut weevil, black vine weevil). After days to months (Table 2), the adults emerge from the host plant or the ground and establish the next generation. Studies on the impacts of EPF on weevils are grouped together based on these life cycle models and discussed in the following sections of this review. Model 1: larvae and pupae both in the host plant; Model 2: larvae in the host plant and pupae under the ground; Model 3: larvae and pupae both under the ground (Table 3).

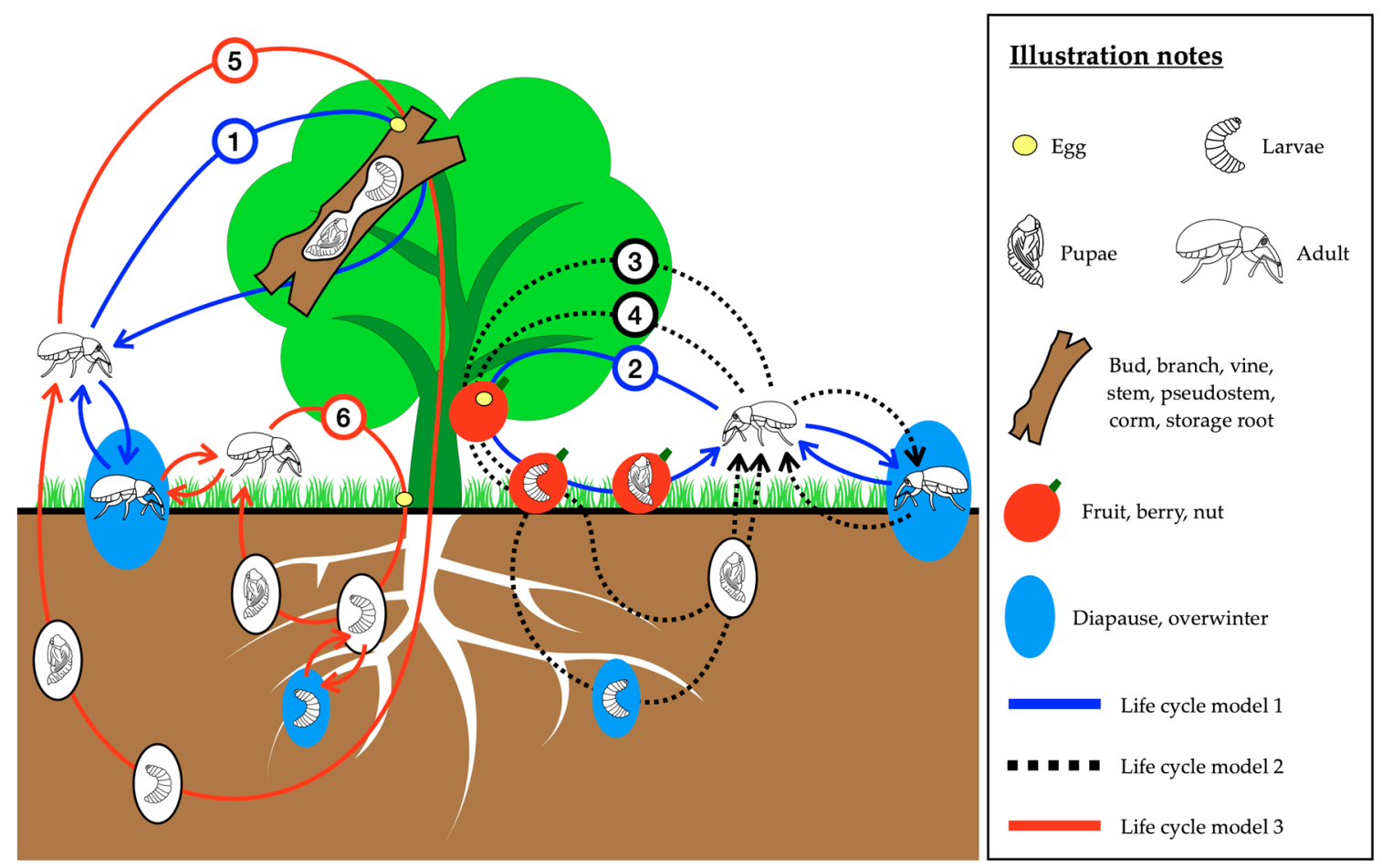

Figure 1. Overview of the life cycles of weevils attacking horticultural crops. The weevil species which were classified into subcategories 1-6 and life cycle models 1-3 in this figure are listed in Table 3. 
Table 3. Major horticultural weevil species used in experiments with EPF grouped according to their different life cycle habitat utilisation models. Subcategories 1-6 correspond to those shown in Figure 1.

\begin{tabular}{|c|c|c|c|}
\hline Life Cycle Model & Subcategory & Weevil Species & Common Name \\
\hline \multirow{16}{*}{$\begin{array}{l}\text { Model 1: Larvae and } \\
\text { Pupae in the Host Plant }\end{array}$} & \multirow{13}{*}{1} & Aclees sp. cf. foveatus & Fig weevil \\
\hline & & Anthonomus signatus & Strawberry bud weevil \\
\hline & & Blosyrus asellus & Rough sweetpotato weevil \\
\hline & & Cosmopolites sordidus & Banana weevil \\
\hline & & Cylas formicarius & Sweetpotato weevil \\
\hline & & Cylas puncticollis & African Sweetpotato weevil \\
\hline & & Odoiporus longicollis & Banana stem weevil \\
\hline & & Pantorhytes plutus & Cacao weevil \\
\hline & & Pityophthorus juglandis & Walnut twig beetle \\
\hline & & Rhynchophorus ferrugineus & Red palm weevil \\
\hline & & Rhynchophorus bilineatus & Black palm weevil \\
\hline & & Scolytus amygdali & Almond bark beetle \\
\hline & & Xyleborus affinis & Ambrosia beetle \\
\hline & & Heilipus lauri & Avocado seed weevil \\
\hline & 2 & Hypothenemus hampei & Coffee berry borer \\
\hline & & Kuschelorhynchus macadamiae & Macadamia seed weevil \\
\hline \multirow{6}{*}{$\begin{array}{l}\text { Model 2: Larvae in the } \\
\text { Host Plant and Pupae } \\
\text { under the Ground }\end{array}$} & \multirow{4}{*}{3} & Curculio caryae & Pecan weevil \\
\hline & & Curculio elephas & Chestnut weevil \\
\hline & & Curculio sikkimensis & Chestnut weevil \\
\hline & & Curculio nucum & Hazelnut weevil \\
\hline & \multirow{2}{*}{4} & Conotrachelus nenuphar & Plum curculio \\
\hline & & Conotrachelus psidii & Guava weevil \\
\hline \multirow{4}{*}{$\begin{array}{l}\text { Model 3: Larvae and } \\
\text { Pupae under the } \\
\text { Ground }\end{array}$} & 5 & Diaprepes abbreviatus & Citrus root weevil \\
\hline & \multirow{3}{*}{6} & Aegorhinus superciliosus & Raspberry weevil \\
\hline & & Otiorhynchus sulcatus & Black vine weevil \\
\hline & & Phlyctinus callosus & Banded fruit weevil \\
\hline
\end{tabular}

\section{Effect of Fungal Entomopathogens on Weevils with Life Cycle Model 1: Larvae and Pupae in the Host Plant}

In total, 61 screening studies have demonstrated the efficacy of Metarhizium spp. and Beauveria spp. on weevils with Model 1 habitat utilisation. The aim of these studies was to find the most effective isolate of each EPF through the evaluation of either commercial strains/products or local isolates. In total, 98 isolates of Metarhizium spp., 275 isolates of Beauveria spp. and 16 commercial strains/products were used for the bioassays. Of the 61 published papers, 55 examined the effects of EPF using aqueous conidial suspensions and only 6 papers examined efficacy using dried conidia applied to different substrates. For bioassays with aqueous conidia, adults or larvae of Aclees sp. cf. foveatus [92], Anthonomus signatus [93], Cosmopolites sordidus [94-102], Cylas formicarius [103,104], C. puncticollis [105], Heilipus lauri [106], Hypothenemus hampei [107-118], Kuschelorhynchus macadamiae [119], Odoiporus longicollis [120-122], Pantorhytes plutus [65], Pityophthorus juglandis [123], Rhynchophorus ferrugineus [124-143], Scolytus amygdali [144] and Xyleborus affinis [76] were immersed for 3-90 s or sprayed with conidial suspensions at varying concentrations. For the studies with dried conidia, C. sordidus $[145,146]$ and R. ferrugineus [147-150] were rolled in (5 $\mathrm{min}$ ) or allowed to walk on dried conidia on substrates such as fungal media, rice or wheat (15 $\mathrm{min}$ to $24 \mathrm{~h}$ ).

Efficacy comparisons between EPF species showed that B. bassiana performed better than M. anisopliae in killing Aclees sp. cf. foveatus [92], C. sordidus [145], H. hampei [111] and H. lauri [106], whilst the opposite result was found with $R$. ferrugineus $[126,147,148]$. Other studies showed that M. anisopliae and B. bassiana were equally effective in killing C. sordidus [95,97,102], C. puncticollis [105], K. macadamiae [119], P. juglandis [123] and R. ferrugineus [129,134,143]. The majority of highly virulent isolates and/or the highest conidial concentrations tested in each study resulted in moderate $(60-80 \%)$ to high levels (>80\%) of mortality in the target weevils, except for C. sordidus [98,100], H. hampei [115] and $X$. affinis [76] where only a low level of mortality was obtained. This could be the result of poor virulence 
of the fungal isolates since the number of conidia used in these studies was high (adults immersed in $10^{8}$ conidia $\mathrm{mL}^{-1}[98,100]$ or spray application at $10^{7}-10^{8}$ conidia $\left.\mathrm{mL}^{-1}[76,115]\right)$. Two studies showed that using biosynthesised silver nanoparticles for disseminating M. anisopliae or B. bassiana could improve efficacy against $R$. ferrugineus by $10 \%$ in comparison to traditional spray applications of conidial suspensions [136,140]. Formulated EPF [92,119,124,127] and non-formulated commercial strains $[107,108,123]$ provided strong and consistent control of weevils with Model 1 habitat patterns under laboratory conditions. For example, Abdel-Samad et al. [124] and Hajjar et al. [127] found that Agronova ${ }^{\circledR}$ and Broadband ${ }^{\circledR}$ products which contain B. bassiana in an oil formulation caused $86-100 \%$ mortality of $R$. ferrugineus when the recommended rate of $10^{9}$ conidia $\mathrm{mL}^{-1}$ was used to treat adults. Castrillo et al. [123] reported that B. bassiana strain GHA and M. brunneum strain F52 at $10^{6}$ conidia $\mathrm{mL}^{-1}$ were highly virulent and caused high mortality (>90\%) of $P$. juglandis 5 days after treatment.

Although the majority of these strains induced moderate $(60-80 \%)$ to high $(>80 \%)$ levels of mortality to weevils in controlled environments, economic control of using EPF in the field may not be achieved as readily. As EPF can take at least 15 days to cause weevil mortality of more than $80 \%$ under field conditions, the targeted weevils are likely to cause at least some damage to the crops either by feeding or laying viable eggs during the intervening period. Twenty-two studies have evaluated the efficacy of EPF on weevils of walnuts, almonds, bananas, coffee, strawberries, sweetpotatoes and palms in the glasshouse or under field conditions. Of these, fourteen examined spray application of EPF onto the plant and four evaluated either the injection of EPF into the space between the stem and petiole insertion point, or application of the dried formulated fungi onto the plant crown before or after weevil establishment. Only four papers discussed the natural occurrence and prevalence of EPF in the field, and these papers involved the control of either C. sordidus [151], H. hampei [152,153] or R. ferrugineus [154]. The stem injection technique was only applied against $R$. ferrugineus larvae and pupae, which remain inside the plant $[131,132,155,156]$, while the spray applications were invariably targeting adult weevils such as A. signatus [157], C. sordidus [97,158], Cylas spp. [159], H. hampei [109,160-163], P. juglandis [123], R. ferrugineus $[125,164,165]$ and S. amygdali [144], which are exposed outside the plant as adults. Variable control was achieved according to the fungal species used [160], fungal persistence [155,157], application technique [125], frequency of the application [163], weather conditions [109,151-153] and insect species. Overall, spray application of the most virulent isolates caused low $(<60 \%)$ to moderate $(60-80 \%)$ levels of mortality to the target weevils, whilst application by stem injection led to moderate to high $(>80 \%)$ mortality of $R$. ferrugineus larvae and pupae.

Eight studies evaluated the effects of incorporating conidia within or on top of topsoil and plant growing media (compost, sawdust) on the mortality of weevils with Model 1 habitat utilisation. These studies aimed to use EPF to control weevils moving through or across the topsoil, plant growing media or across infective fungal substrates used to create a protective barrier around host plants. Of the eight papers, three examined mortality under laboratory conditions and five assessed efficacy in the glasshouse or field. In the laboratory, EPF were sprayed or applied to the soil or growing media before introducing the weevils. High mortality $(>80 \%)$ of the weevils (C. formicarius and R. ferrugineus) occurred [126,166], except in the study by Francardi et al. [149]. The low mortality $(12-20 \%)$ of R. ferrugineus recorded by Francardi et al. [149] could be the result of there being insufficient conidia in the soil to adhere to and infect the adults. This was confirmed by the same authors who replaced soil with conidiated rice for adults to move across, improving the mortality rate to more than $85 \%$ [149]. However, only low $(<60 \%)$ to moderate $(60-80 \%)$ mortality of weevils was achieved in the field when this treatment method was used $(24 \%$ to $63 \%, 8 \%$ to $75 \%$ and 25 to $62 \%$ for C. sordidus $[167,168]$, H. hampei $[113,169]$ and P. juglandis [90], respectively). This may have been a consequence of insufficient amounts of conidia being applied, the long period between fungal application and the emergence of adult weevil populations, and/or the effect of the unstable microclimate near the topsoil where there would have been large fluctuations in temperature and humidity. This issue is discussed further in the section on weevils with Model 2 and 3 habitat utilisations. 
In order to improve weevil management, combinations of EPF with other biological control agents (BCAs) and attractants have also been explored. Three studies evaluated synergistic interactions of EPF with entomopathogenic nematodes (EPNs) and Bacillus thuringiensis against $R$. ferrugineus [170-172]. Saleh et al. [171] reported that B. bassiana behaved synergistically with Steinernema carpocapsae (EPNs) and killed R. ferrugineus adults in just $24 \mathrm{~h}$ when both BCAs were co-applied. In contrast, Wakil et al. [172] reported that EPF and EPNs could not be applied at the same time. They found that 72-89\% mortality of R. ferrugineus larvae could be obtained when EPNs (Heterorhabditis bacteriophora) were applied two weeks after B. bassiana or M. anisopliae. However, low mortality (below 30\%) was observed when EPF or EPNs were applied alone, or 45-61\% mortality when EPF and EPNs were applied simultaneously, supporting the synergy between EPF and EPNs when used with appropriate timings [172]. Malik et al. [170] reported that $B$. thuringiensis behaved synergistically with $B$. bassiana for managing $R$. ferrugineus. When both entomopathogens were co-applied on $R$. ferrugineus larvae they caused substantially more mortality and reduced the percentages of pupation and adult emergence than B. bassiana or B. thuringiensis used alone [170].

Combinations of EPF with attractants such as a methanol/ethanol mixture, aggregation pheromones or sex pheromones were tested against C. sordidus [173-175], C. formicarius [176], H. hampei [115] and R. ferrugineus $[127,177-180]$. The term "sex pheromone" is commonly defined as the chemical signals from a female to attract males of the same species for initiation of courtship or mating, whereas an "aggregation pheromone" is a male-produced attractant which draws both sexes of the same species to a calling site to increase mating likelihood [181]. The aims of these studies were to infect adult weevils with EPF by integrating the EPF with attractants as an "attract-and-infect" technique. They showed that the integration of $B$. bassiana with an aggregation pheromone component (ferrugineol or 4-methyl-5-nonanol) in the infective trap could cause high mortality to $R$. ferrugineus adults in the laboratory, but only low to moderate mortality was observed in the field [127,177-180]. Despite this apparent limitation, studies have found that the combination of B. bassiana with ferrugineol as part of an attract-and-infect strategy reduced infestations of $R$. ferrugineus $[178,179]$ more effectively than the application of the insecticide chlorpyrifos alone, or the combination of chlorpyrifos with ferrugineol in an attract-and-kill system [178]. Moderate to high mortality of C. sordidus adults was also observed in the laboratory when $B$. bassiana was combined with an aggregation pheromone (Cosmolure ${ }^{\circledR}$-sordidin or (1S,3R,5R,7S)-1-ethyl-3,5,7-trimethyl-2,8-dioxabicyclo [3.2.1] octane) [174], but again only low to moderate mortality was obtained in the field [173,175]. Similarly, Mota et al. [115] reported that only moderate mortality of $H$. hampei was observed in the auto inoculation trap containing methanol/ethanol mixture (at 1:1 v/v) and a B. bassiana suspension. In contrast, Yasuda [176] demonstrated high levels of control by combining B. bassiana conidia with sex pheromones inside a trap for controlling $C$. formicarius in the field. Although this study showed the potential for combining EPF with attractants, many others have failed to provide good control of adult weevils in the field. In the case of H. hampei, poor trap design [182], attractant compound selection, and inappropriate timing in relation to the emergence period of the adults $[115,183]$ contributed to the failure of this technique. Pereira et al. [183] found that methanol/ethanol mixture is not specific to H. hampei and many scolytids including "false H. hampei"were also captured in the trap. Mota et al. [115] reported that the number of H. hampei captured in the trap fluctuated over 22 weeks of the experiment with the noticeable peaks of adult captures at the 5 th and 7 th week of the trap placement in the field. The same issues with inappropriate timing in relation to the emergence period of the adults were also raised by Sewify et al. [184] and Vacas et al. [185] in their studies on R. ferrugineus. Dembilio et al. [179] reported that conidia viability inside the trap significantly reduced over time, from $100 \%$ on day 1 to less than $50 \%$ at day 67 , and, as a consequence, only low to moderate mortality was observed in the field. From these studies, it is obvious that to be effective combinations of EPF with attractants designed to enhance infection rates must be used when adult weevil activity is high, and utilise reliable attractants with good persistence in the field. Other key areas of work needed to optimise attract-and-infect systems include the improvement of EPF persistence in the trap, as well as enhancing the capacity of EPF conidia to adhere to the weevils. 
An advantage of the attract-and-infect technique with EPF is the ability to generate local transmission between adults in the first cycle $[127,173,179]$ and to some extent between adults and conidiated cadavers in the second cycle. The mortality of the "recipients" was around 16\% for C. sordidus and $45 \%$ for R. ferrugineus when adults that had previously visited traps and served as "donors" had physical contact with them $[127,173,179]$. Studies showed that copulation is the main basis for disease transmission between adults via physical contact. Many studies have shown that an infected male is able to transmit EPF and subsequently cause mortality to the females, or vice versa $[94,124,165,186,187]$. Horizontal transmission did not just kill the female adults, but also reduced the number of eggs produced and egg viability by 44 to $68 \%$ and by 45 to $55 \%$, respectively, for C. formicarius [186] and R. ferrugineus [125] before the females died. Interestingly, the percentage of egg viability of $R$. ferrugineus was reduced by $86-100 \%$, after the female mated with the reproductively sterile male (gamma irradiated) carrying B. bassiana [188]. After adults were killed by EPF, the conidiated cadavers were also found to generate a second cycle of disease transmission. Dotaona et al. [186] reported that one conidiated cadaver could cause $63 \%$ mortality (of 10 adults) to C. formicarius under laboratory conditions. From these findings, infected adult weevils and conidiated cadavers have an important role in recycling and transmitting EPF within pest populations.

In addition to the capacity for horizontal transmission, EPF were also found to produce volatile organic compounds (1-octen-3-ol, 2-octen-1-ol, 3-octanol, 3-octanone) and acetic acid, which behave as repellent volatiles [189,190]. Dotaona et al. [191] found that $C$. formicarius showed avoidance behaviour toward the most virulent isolates of $M$. anisopliae when compared to controls or low virulence isolates. In contrast, Leng and Reddy [192] found that C. formicarius showed no avoidance behaviour toward B. bassiana, but avoidance was observed toward neem (a botanical insecticide), petroleum oil and the insecticide spinosad. The variation between these two studies could be explained by the work of Bojke et al. [189] who demonstrated that M. anisopliae was able to produce volatile organic compounds and acetic acid, whereas B. bassiana could not. In addition to producing potentially repellent volatiles, some EPF have been reported to have the ability to become endophytes within host plants and decrease the survivorship of weevils feeding on these hosts. Akello et al. [193,194] found that B. bassiana was a symbiont with banana plants and caused $53-58 \%$ mortality to $C$. sordidus adults. This reduced the population of the next generation by about $23-89 \%$, leading to a reduction of crop damage by $42-87 \%$. Similarly, Prabhavathi and Ghosh [87] also found that B. bassiana could colonise banana tissue for at least four months after dipping the corm in a conidial suspension and caused $50-70 \%$ mortality to O. longicollis. Date palm seedlings can also be endophytically colonised by B. bassiana, leading to 70-80\% mortality of $R$. ferrugineus larvae when they fed on the endophytic plant in the laboratory [195].

Although numerous studies have confirmed the potential of EPF to suppress weevils in the laboratory, their variable results on horticultural crops under field conditions could lead to confusion amongst end-users or those seeking to develop and register commercial products. In order to give a better understanding of the overall potential of EPF, eleven studies have compared EPF with synthetic insecticides individually or evaluated their simultaneous use. Of the eleven papers, two showed significantly better control by EPF in comparison to synthetic insecticides alone [196,197], but another five showed the opposite result—synthetic insecticides provided superior control [43,96,192,198,199]. Only four papers have discussed synergistic interactions of EPF with sublethal doses of botanical and/or synthetic insecticides [139,200-202]. The combination of EPF with sublethal doses of neem and spinosad killed $100 \%$ of $C$. formicarius within $48-72 \mathrm{~h}$; however, the application of the full recommended doses of either the insecticides or EPF alone took more than $72 \mathrm{~h}$ to kill $100 \%$ of adult weevils in the laboratory [200]. Malik et al. [202] found that the combination of B. bassiana with a sublethal dose of imidacloprid killed $100 \%$ of $R$. ferrugineus larvae within 20 days, whereas the same sublethal dose of imidacloprid or B. bassiana alone killed only $84 \%$ and $54-77 \%$ of the larvae, respectively. Again, Saleem et al. [201] and Qayyum et al. [139] found that B. bassiana showed synergy with a sublethal dose of nitenpyram for the control of $R$. ferrugineus adults and larvae and provided superior control to either treatment applied alone. 


\section{Effect of Fungal Entomopathogens on Weevils with Life Cycle Model 2: Larvae in the Host Plant and Pupation under the Ground}

Seven screening studies have demonstrated the efficacy of Metarhizium spp. and Beauveria spp. against weevils with Model 2 habitat utilisation. In total, 28 isolates of Metarhizium spp. and 13 isolates of Beauveria spp. were used for these screening studies. Of the seven papers, five examined the effect of EPF using aqueous conidial suspensions [203-207] and two evaluated the use of dried conidia previously cultured on fungal media [208,209]. For the tests with aqueous conidia, adults or larvae of Conotrachelus nenuphar [203], Curculio caryae [204], Curculio nucum [205] and Curculio sikkimensis [206,207] were immersed for 8-60 s or sprayed with conidial suspensions at different concentrations. For the tests with dried conidia, C. caryae and C. nenuphar were infected by being allowed to walk or crawl for several minutes on a conidiated fungal culture [208,209]. The overall results indicated that the most virulent isolates of $B$. bassiana and $M$. anisopliae induced high mortality $(>80 \%$ ) to the population of weevils treated with aqueous conidia whereas $74-83 \%$ mortality of $C$. caryae and $98-99 \%$ mortality of C. nenuphar were obtained with the dried conidia treatments. In terms of the efficacy comparison between B. bassiana and M. anisopliae, B. bassiana was more active against C. caryae [208]; however, the opposite result was obtained with C. sikkimensis [207] and C. nucum [205].

Seventeen further papers evaluated the effect of fungal conidia applied onto or incorporated into topsoil and plant growing media (vermiculite, soybean straw) on the mortality of weevils with Model 2 habitat utilisation. These studies aimed to evaluate EPF for control of either larvae below the ground, or adult weevils moving on the ground or on plant growing media. Nine studies were conducted in the laboratory and the remaining studies assessed efficacy under field conditions with the most virulent isolates and commercial strains/products (M. brunneum strain F52, B. bassiana strain GHA-Mycotrol ${ }^{\circledR}$, Botanigard ${ }^{\circledR}$, B. bassiana strain ATCC 74040-Naturalis $\left.{ }^{\circledR}\right)$. In the laboratory, EPF were sprayed or applied as a drench onto the soil or plant growing media and left for 1-24 h before the introduction of larvae or adults onto the sprayed surface. Moderate (60-80\%) to high $(>80 \%)$ mortality of weevils such as C. nenuphar, C. caryae, C. elephas and C. nucum was obtained after treatment with virulent isolates [209-212], Mycotrol ${ }^{\circledR}$ and Naturalis ${ }^{\circledR}$ [213-215] but only low $(<60 \%)$ to moderate (60-80\%) levels of control were achieved when adult weevils or larvae (e.g., C. caryae) were introduced four days after EPF application $[208,216]$. Low to moderate mortality of C. caryae [204,217,218], C. sikkimensis [206,207], C. nucum [219] and C. nenuphar [220] was also achieved in the field after the application of virulent EPF isolates or commercial products (Beaupro ${ }^{\circledR}$, Metapro ${ }^{\circledR}$ and Botanigard $\left.{ }^{\circledR}\right)$, suggesting that the weevils moved onto the ground several days after fungal application [208,216]. To mitigate poor infectivity of EPF in the field, Shapiro-Ilan and Brown [215] suggested that using earthworms (Lumbricus terrestris) as phoretic hosts for B. bassiana in the soil could improve fungal infectivity in comparison to the more traditional applications of EPF directly to the topsoil. Other studies found challenges still remain that complicate efforts to control pecan weevils successfully with EPF. Shapiro-Ilan et al. [221] found that high infectivity of EPF did not persist in the field for longer than one week after application. The number of conidia recovered from field soil declined significantly one week after application, from around $6.5 \times 10^{3} \mathrm{CFU} / \mathrm{g}$ of soil at day 1 to around $3 \times 10^{3} \mathrm{CFU} / \mathrm{g}$ of soil at day 8 in a 2009 trial and from $9 \times 10^{2} \mathrm{CFU} / \mathrm{g}$ of soil at day 1 to $1 \times 10^{2} \mathrm{CFU} / \mathrm{g}$ of soil at day $8 \mathrm{in}$ a trial conducted during 2010 [218]. The number of conidia recovered from the soil continued to drop to almost zero by day 29 in both years [218]. The authors suggested that conidial densities declined rapidly because there was no mulch or cover crop to provide protection from UV radiation penetrating the crop canopy and contribute towards stabilising topsoil temperature and humidity [218]. Shapiro-Ilan and Mizell [222] also found that the pupal cell of C. caryae had antimicrobial properties that had the potential to inhibit penetration and infection by the fungi. Long gaps between fungal application and weevil activity, poor persistence and uneven distribution of EPF in the field, and antimicrobial properties of the pupal cell are all factors that can contribute to the reduced efficacy of fungal applications in the field. 
Only four studies have evaluated the efficacy of EPF on weevils of pecan in the field. Spray applications targeting $C$. caryae adults on the plant showed that the most virulent isolates of $M$. anisopliae and Botanigard ${ }^{\mathbb{R}}$ (containing B. bassiana strain GHA) caused moderate $(60-80 \%)$ to high $(>80 \%)$ levels of mortality to C. caryae whilst M. brunneum strain F52 caused low ( $<60 \%)$ to moderate $(60-80 \%)$ mortality $[217,223-225]$. Interestingly, spray applications of EPF on the plant caused slightly higher mortality of $C$. caryae than the application of EPF on the ground $[217,223,225]$. Although moderate to high mortality of $C$. caryae was achieved, the authors noted that economic control was not achieved as the EPF required weeks to kill the weevils, during which time the weevils continued to cause damage to the crop. Although mortality may have been delayed, these infected adults may play an important role in the horizontal transmission of EPF, providing more effective control in the longer term. In the case of $C$. caryae, infected males or females were able to transmit EPF via contact during mating, leading to $50 \%$ mortality in their partners [216].

As fungal applications to the ground and foliage have not achieved the optimum level of control, EPF have been tested and integrated with other components of IPM programs including chemicals and other biological control agents. Combinations of EPF with EPNs (Heterorhabditis bacteriophora, Steinernema carpocapsae, S. feltiae) induced moderate $(60-80 \%)$ to high $(>80 \%)$ levels of mortality of C. caryae, C. elephas and C. nucum larvae $[210,226,227]$. These combinations (EPF + EPNs) did not, however, provide any significant advantages over individual treatments (EPF or EPNs alone), which also caused good levels of mortality in the targeted weevils. This was confirmed by Shapiro-Ilan et al. [228] who found that EPF + EPNs did not result in mortality of C. caryae higher than that caused by EPF or EPNs alone, and by Batalla-Carrera et al. [210] and Asan et al. [227] who reported that the mortality of C. elephas and C. nucum caused by EPF + EPNs and EPF alone did not differ. It is difficult to draw direct comparisons between EPF and EPNs because their mode of action and their effective concentrations are different. Studies show that when EPF or EPNs are applied on the topsoil before introducing weevil larvae, the EPNs provide better control of both C. caryae [226] and C. nenuphar [220] compared to EPF. However, when larvae are immersed in the fungal suspension and compared with EPNs (applied on the topsoil), the mortality of both C. elephas [227] and C. nenuphar [203] caused by EPF was always higher than that caused by EPNs. These studies suggest that in many cases EPNs are likely to provide better control of weevils active below the soil surface than EPF. This is discussed further in the following sections.

Combinations of EPF with synthetic insecticides have shown their potential synergy, with $100 \%$ control of weevils including C. caryae [229] and C. psidii [230]. When B. bassiana was applied together with a sublethal dose of imidacloprid to C. psidii, $100 \%$ mortality of adults was recorded; however, the application of B. bassiana alone killed only $62 \%$ of weevils and the sublethal dose of imidacloprid alone did not kill any [230]. The sublethal dose of imidacloprid increased the vulnerability of weevils to EPF, presumably by diverting metabolic activity to insecticide detoxification and thereby reducing the insect's capacity to resist fungal infection. The authors also observed that the sublethal dose of insecticide had a substantial impact on the insect's grooming behaviour [230]. The impact of sublethal doses of insecticides on the grooming behaviour of weevils and its implications for EPF efficacy will be discussed further in the section on weevils with Model 3 habitat utilisation.

\section{Effect of Fungal Entomopathogens on Weevils with Life Cycle Model 3: Larvae and Pupae under the Ground}

Twelve screening studies have demonstrated the efficacy of Metarhizium spp. and Beauveria spp. on four weevils (Aegorhinus superciliosus, Diaprepes abbreviatus, Otiorhynchus sulcatus and Phlyctinus callosus) with Model 3 habitat utilisation. In total, 56 isolates of Metarhizium spp., 29 isolates of Beauveria spp. and 7 commercial strains/products were used for these screening studies. All studies examined the effects of EPF using aqueous conidial suspensions. Larvae or adults of A. superciliosus [231], D. abbreviatus [232], O. sulcatus [233-241] and P. callosus [242] were immersed for 10-60 s, exposed to a topical application, or sprayed with conidial suspensions at different concentrations. The comparison 
of Metarhizium spp. and Beauveria spp. showed that Metarhizium spp. often performed better than Beauveria spp. against O. sulcatus [235-237], although some studies found that both fungi were equally effective in killing O. sulcatus and P. callosus [238,240,242]. In general, the majority of the most virulent isolates or commercial strains/products and/or the highest concentration used in each study caused moderate $(60-80 \%)$ to high $(>80 \%)$ level of mortality to the target weevils.

At least 17 papers have evaluated the effect of application or incorporation of fungal conidia into or onto topsoil or plant growing media (bark-based potting medium, peat-based media, spent mushroom compost, peat moss, peat compost, turkey grit) on weevil mortality. These studies aimed to use EPF to control target insects as below-ground larvae, or as adults dispersing across the soil surface towards a plant host. Conidia were sprayed onto or drenched into the soil or plant growing media before introducing larvae or adults onto the treated surface under laboratory conditions. Moderate (60-80\%) to high $(>80 \%)$ mortality of the weevils was observed [236,243-254]. The commercial strains/products Met $52{ }^{\circledR}$ and Naturalis ${ }^{\circledR}$ showed strong and consistent control of weevils and caused high $(>80 \%)$ levels of mortality $[248,250,254]$. However, application of Met52 ${ }^{\circledR}$ as a topsoil drench in the field provided only low mortality of $O$. sulcatus larvae [255]. Moderate to high mortality of the weevils resulted when conidiated rice was applied directly on the topsoil, providing an infective layer for controlling the larvae of this species $[256,257]$ suggesting this approach may provide sufficient conidia on the topsoil to adhere to and cause mortality to O. sulcatus. The mortality of $O$. sulcatus was high in the first week after EPF were incorporated with a bark-based potting medium, but mortality decreased to moderate $(60-80 \%)$ levels after 77 days [249] and zero after 1 year [258]. This is likely the result of conidia degradation, as observed by Bruck [248] who reported that the number of conidia recovered from peat-based and bark-based potting media reduced gradually; from around $1 \times 10^{6.5} \mathrm{CFU} / \mathrm{g}$ dry potting media at week 2 to around $1 \times 10^{5.5} \mathrm{CFU} / \mathrm{g}$ dry potting media at week 48 . Shapiro-Ilan et al. [218,225] reported the number of conidia recovered from topsoil dropped to almost zero 7 weeks after an EPF application in the field. To minimise rapid conidial degradation in the field, several studies have recommended that EPF should be incorporated with pasteurised potting media (such as peat-based and bark-based potting media) for at least one week before use $[248,250]$. This allows the EPF to adjust to the media and grow in controlled conditions with good moisture levels and nutrients before being used in the field.

Pope et al. [238] found that the use of M. brunneum (F52) conidial powder in Roguard refuges (black plastic crawling insect stations) provided at least $93 \%$ control of O. sulcatus after 28 days. Deployment of B. bassiana (GHA strain) under the same conditions provided only $27-67 \%$ weevil mortality. Other studies have also demonstrated that Metarhizium spp. perform better than Beauveria spp. against O. sulcatus [235-237]. Baits or attractants are not essential in Roguard refuges for O. sulcatus control since adults of this weevil are nocturnal and move inside the station during the day to avoid exposure to sunlight [64]. The recent development of lures ((Z)-2-pentenol + methyl eugenol) for O. sulcatus [259] has, however, improved the attractiveness of the refuges, and deploying the lures with an EPF formulated in linseed oil within the refuges has provided very effective control of O. sulcatus in the field [260].

The behaviour of weevils in response to volatiles produced by EPF has also been explored. Rondot and Reineke [261] found that $O$. sulcatus has the ability to detect EPF and avoids the commercial product Naturalis ${ }^{\circledR}$ and Kepler and Bruck [262] showed that whilst O. sulcatus does not avoid M. brunneum (strain F52), it does avoid the insecticide bifenthrin. Although O. sulcatus showed avoidance behaviour in response to Naturalis ${ }^{\circledR}$ [261], this could be a response to additives in the commercial product rather than to B. bassiana itself. A recent study found that B. bassiana does not produce repellent volatiles [189].

Entomopathogenic fungi synergism with other entomopathogens and insecticides has also been studied in relation to weevils with Model 3 habitat utilisation. Fungal entomopathogens were applied alone or together with EPNs (Heterorhabditis bacteriophora, Steinernema kraussei and S. feltiae) on the topsoil and plant growing media (peat-based media) before introduction of $O$. sulcatus larvae. High mortality of larvae was obtained when Metarhizium spp. were combined with EPNs in the 
laboratory, glasshouse and to an extent in the field [263-265]. Metarhizium spp. seemed to dominate the detrimental effects on the larvae; when used individually, the mortality of larvae caused by Metarhizium spp. alone was $40-88 \%$ in the glasshouse and $88-94 \%$ in the field, and the mortality of the larvae caused by the EPNs was 30-69\% in the glasshouse and 20-75\% in the field [263-265]. High levels of mortality were also found when EPF were applied together with synthetic insecticides against weevils in this group. More than $90 \%$ mortality of D. abbreviatus and O. sulcatus occurred when EPF were applied together with sublethal doses of imidacloprid, fipronil or neem either directly or via peat-based plant media (a combination of peat, bark, coir and compost) before introduction of the larvae [266-270]. However, the application of either EPF or sublethal doses of insecticides alone caused only low $(<60 \%)$ to moderate $(60-80 \%)$ mortality of the target weevils. The lower mortality of the larvae treated with EPF alone is attributed to below-ground movement of the larvae leading to the passive removal of conidia as the larvae moved against soil particles, or active removal associated with grooming behaviour [266-268]. The removal of fungal conidia during grooming has also been observed in adults [271]. A sublethal dose of imidacloprid led to reduced or temporary loss of mobility by the larvae, which were then unable to remove fungal conidia from their cuticle [266-268].

\section{Integration of Fungal Entomopathogens in the Integrated Pest Management Programs and Future Research Directions}

Entomopathogenic fungi have shown potential to control many weevil species associated with horticultural crops under laboratory conditions, but wide variations in weevil mortality are commonly seen across different fungal species, isolates and strains. In some cases, the fungal strains which were isolated from particular weevils have shown limited capacity to control that species (e.g., coffee berry borer, H. hampei [108,112], banana weevil, C. sordidus [96,97] and red palm weevil, R. ferrugineus [128]). In contrast, other studies have shown that strains of EPF which naturally infect target weevils work better against those species than strains baited from the soil, commercial strains, or commercial formulated products $[94,95,115,132]$. As there are no consistent patterns in these studies, it is most appropriate to use a registered commercial strain as a reference strain and compare this with any newly isolated strains in screening studies. This will provide more useful baseline data on the relative virulence of new strains, which should be assessed on their potential to provide improvements relative to existing commercial products rather than relative to other, often randomly selected experimental isolates.

Although there were only four studies on the response of weevils to B. bassiana deployed as fungal endophytes in plants (all life cycle habitat utilisation Model 1 species) [87,193-195], the establishment of endophytic plants is an effective preventive tactic, and a practical solution for managing weevils of horticultural crops. In addition to causing mortality of the weevils, endophytic plants may have less damage and yield loss, as the fungi that colonise the host plant $[193,194]$ probably produce insecticidal metabolites which may improve the resistance of the host plant to attack $[16,272,273]$. The establishment of fungal endophytes within annual crops has often been noted [272,273]; however, no studies have been performed on perennial crops that have extended beyond the seedling stage. Studies on seedlings have included those on pecan [274], cacao [275], coffee [276], and those on isolated plant parts [277-279]. Further research on the protection provided by fungal endophytes in mature perennial crops is needed, with a focus on the persistence of endophyte activity in the plant and correlating this to effects on pest populations. The methodology for confirming endophytic activity is crucial for separating the effects of endophytes from those associated with epiphytic fungi [16].

The application of EPF incorporated into plant growing media around and below crops to produce a "contamination layer" or "infective zone" has been shown to provide long-term control of adult and larval weevils. Incorporating EPF with pasteurised organic fertilizers, compost or growing media [248-250] in combination with zero-tillage [280,281] may improve not just the abundance, but also the persistence of EPF in the soil. This approach may help compensate for the problems associated with the limited durability and infectivity of EPF in horticultural crops. Although EPF can in some cases persist in the soil for long periods [282] (up to 15 years in exceptional cases [283]), a single application 
of EPF on the topsoil may have only short-term benefits for pest management, as the fungal density usually decreases gradually after application. This theory is supported by many studies $[237,284,285]$; however, despite its transient nature, the application of compost, organic fertilizer or plant growing media colonised by EPF around crops probably represents the best EPF-based technique to control weevils that have a predominantly subterranean pattern of habitat utilisation. More importantly, this solution is suitable for organic growers who are required to use only compost or organic fertilizer on their crops.

Identification of effective attractants for additional weevil species should allow further development of attract-and-infect or attract-and-kill techniques utilising the most virulent strains of EPF, helping to minimise application and management costs. Integration of EPF (particularly B. bassiana and $M$. brunneum) with an attractant was far more effective than combining the attractant with insecticides [178] because weevils were able to detect and avoid many insecticides (e.g., bifenthrin [262], spinosad, neem, petroleum oil [192]), whereas B. bassiana and M. brunneum do not produce repellent compounds [189] and are consequently suitable to integrate with attract-and-kill systems. The use of adhesive carriers for conidia, such as electrostatically charged powders, will also help to improve the success of attract-and-infect and attract-and-kill techniques. This approach has been successfully integrated with both EPF and synthetic pesticides to control stored product pests [286-288], varroa mites [289], and mosquitoes [290]. Carriers improve the ability of conidia to transfer more easily to the insect and in sufficient numbers to cause mortality, both directly or by subsequent transfer to other individuals. Although attract-and-infect and attract-and-kill systems are good in theory, these techniques may not be applicable to all species, since attractants may be difficult to identify and synthesise, and some species may not utilise pheromones for aggregation or mate location to begin with. Where pheromones or other attractants are known, however, their integration with EPF in these sorts of systems represents a great opportunity for reducing dependence on synthetic insecticides.

One of the most interesting techniques for utilising EPF involves the horizontal transmission of conidia from male weevils sterilised using ionising radiation (Figure 2). Of the journal papers examined in this review, only one paper tested this technique. Significant control of the red palm weevil R. ferrugineus was reported [188] and the sexual competitiveness of sterile males was not reduced by sterilisation when compared to non-sterile males [291]. The combination of the sterile insect technique (SIT) with EPF has also been tested on fruit flies including Mexican fruit fly (Anastrepha ludens) [21], Mediterranean fruit fly (Ceratitis capitata) [19], melon fly (Bactrocera cucurbitae) [20], and peach fruit fly (Bactrocera zonata) [292]. The sterile insect technique alone or used in combination with EPF has shown potential for safe and selective pest control, but, since sterilisation may have a negative impact on sexual competitiveness [21], further research on optimising sterilisation procedures is needed for each species being targeted.

Although commercial strains of EPF have been regularly used in the field, only moderate levels of control have been obtained $[217,218,220,223,225]$. This is largely attributable to the negative impact of unfavourable weather conditions [293]. There have been many efforts to improve the formulation of EPF to withstand unfavourable environmental conditions including high temperatures and UV radiation [294,295], but recent efforts have been focussed on finding weather tolerant strains [296,297] and understanding and improving the tolerance of the fungi themselves to heat and sunlight [298,299].

To the best of our knowledge, EPNs and B. thuringiensis are the only other biological control agents to be experimentally integrated with EPF. As the mode of action of B. thuringiensis is by ingestion, it is suitable for integration with EPF for application to aerial parts of the host plant rather than to the topsoil, and this represents a useful approach for controlling weevil adults feeding on the crops. Several studies have shown the potential of $B$. thuringiensis toxins for controlling weevils of horticultural crops including C. puncticollis, C. brunneus, and D. abbreviatus [300,301] and stem from the findings of Malik et al. [170] that B. thuringiensis is suitable to integrate with EPF for controlling other weevil species. Entomopathogenic nematodes are suitable to integrate with EPF for application to the ground rather than to the trunk or foliage of the plant, and this represents a useful approach for controlling 
larval weevils with life cycle habitat utilisation Models 2 and 3 (Figure 2). Almost all combinations of EPF with EPNs have proven to be positive and caused significant mortality to the target weevils (e.g., R. ferrugineus, C. nenuphar, C. caryae, C. elephas, C. nucum and O. sulcatus) which they were tested against. In addition, the rotational application of EPF and EPNs at two-week intervals was found to be effective against weevils, especially by Anbesse et al. [302] who also found that three-week intervals were effective. The simultaneous or sequential applications of EPNs and EPF on the soil surface or onto plant growing media produces a "contamination layer" or "infective zone" that brings larval weevils and the biological control agents into close contact, facilitating infection. Entomopathogenic nematodes seem to have an advantage for controlling larvae with Model 2 and 3 habitat utilisation patterns, as they are active entomopathogens, able to move freely in the soil and ambush their hosts which are active below the soil surface. In contrast, EPF are passive entomopathogens and insect infection relies on movement of the host to provide contact with the conidia, particularly when the larvae exit from plant tissues and move into the soil. Achieving EPF infection in weevil larvae living more than a few centimetres below the soil surface is particularly difficult and highlights the need for control methodologies to be chosen based on a thorough knowledge of pest biology and the persistence of entomopathogens in the rhizosphere.

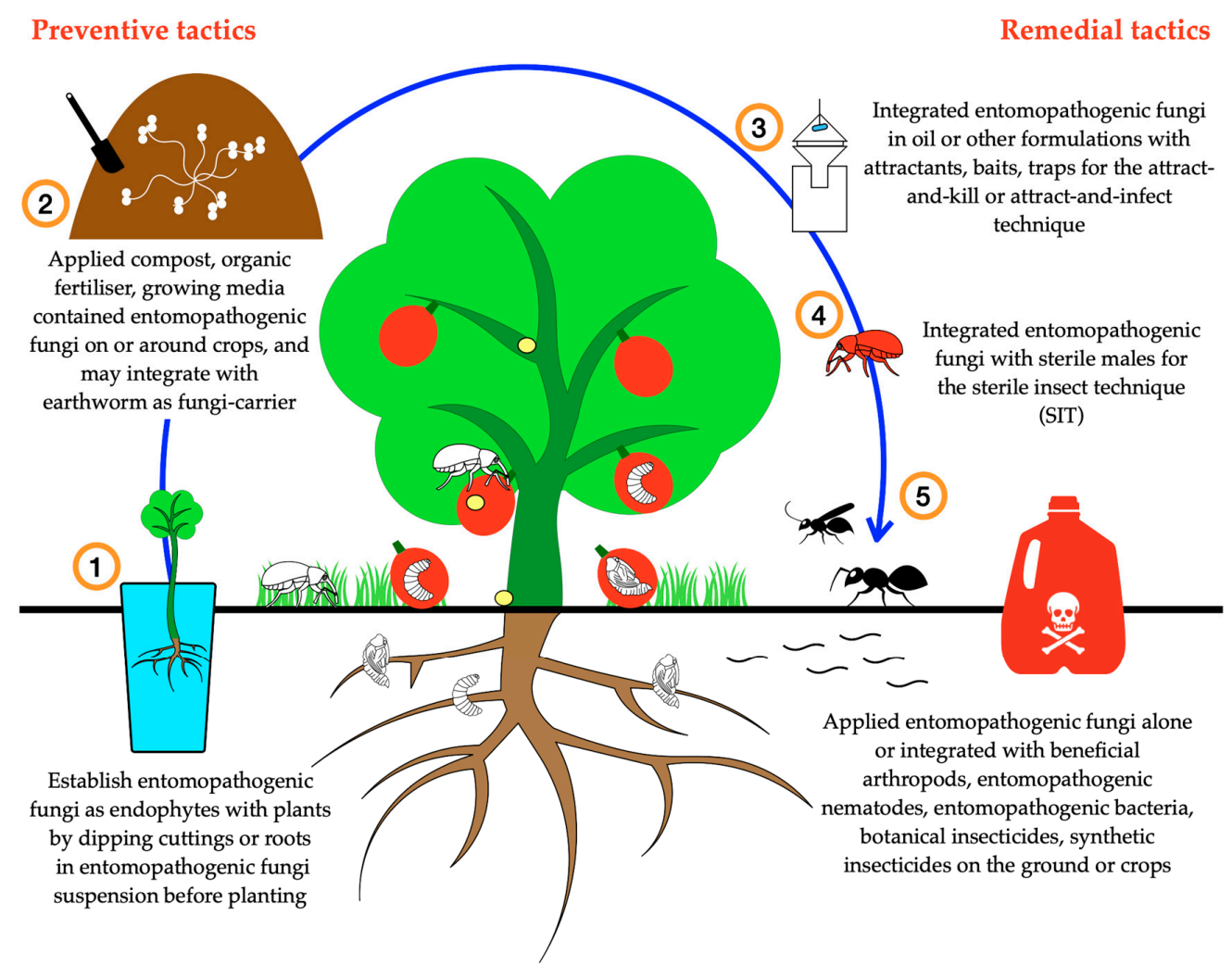

Figure 2. Conceptual illustration of potential uses of entomopathogenic fungi in IPM programs for managing weevils of horticultural crops.

Several studies have focused on the direct effect of EPF on predators of $A$. signatus (e.g., the generalist predatory bug Anthocoris nemorum [303]), C. sordidus and R. ferrugineus (e.g., the predatory earwig Euborellia annulipes [304]), D. abbreviatus (e.g., Asian lady beetle Harmonia axyridis and the generalist predatory lady beetle Olla v-nigrum [305-307]) and parasitoids of H. hampei (e.g., the bethylid ectoparasitoid Prorops nasuta [308], egg parasitoid Trichogramma pretiosum [309-311], eulophid endoparasitoid Phymastichus coffea [312] and bethylid ectoparasitoid Cephalonomia stephanoderis [313]). These studies indicate that the integration of EPF with predators and parasitoids should be feasible, but EPF should be applied at different times relative to any supplementary releases of beneficial insect 
species. For example, to effectively integrate EPF with T. pretiosum (an egg parasitoid), studies suggest that $T$. pretiosum should be released around three days prior to the application of EPF on crops and the second application of EPF should be delayed for a minimum of seven days after the first application. This timing ensures that when the EPF is applied the majority of parasitoids are developing within host eggs, rather than being exposed to the EPF as adults, since the development of T. pretiosum from egg to adult takes around one week [309,310]. Application of EPF to host eggs already parasitised by T. pretiosum did not have any negative impact on subsequent emergence of the parasitoid [309,310]. In contrast, the application of EPF to crops before releasing adult T. pretiosum may lead to T. pretiosum avoiding oviposition into host eggs already infected by the EPF $[309,310]$. The generalist predatory bug A. nemorum is known to avoid prey that are already infected by EPF and the avoidance behaviour was more pronounced towards conidiated cadavers. In addition, adults also avoided laying eggs on the plants that had already been treated with EPF [303]. Although these examples recommend releasing parasitoids and predators before the application of EPF, the optimum timing of EPF applications relative to releases of predators or parasitoids is likely to be specific to each combination of pest, EPF and beneficial species involved, and further studies in this area are required.

Some combinations of EPF with sublethal doses of botanical and synthetic insecticides have been shown to be synergistic and this interaction can also provide an effective solution for the management of weevils on horticultural crops. Combination treatments may work better than applications of either EPF or insecticide alone because the insecticide may disrupt insect grooming behavior that would otherwise lead to the removal of conidia before their germination [266-268,271]. Vulnerability to fungal infection in the insects may also be increased as a consequence of stress caused by insecticide exposure [230]. Although these combinations often show positive results, the use of sublethal insecticide doses may not be possible in field applications due to regulatory requirements designed to specifically combat resistance to standalone insecticide treatments caused by underdosing. In addition, not all synthetic insecticides are synergistic with EPF. In some studies, synthetic insecticides were toxic to EPF in tank mixes [314] and combined applications cannot be recommended. Adverse interactions may be a consequence of either the active ingredient or formulation additives being toxic to the entomopathogens [314]. Modifying the insecticide formulation may help avoid this problem; however, if the active ingredient is toxic to the fungus, the only viable option may be to separate the applications in time, and this requirement may be particularly significant with regard to the potential development of pesticide resistance.

\section{Conclusions}

In conclusion, entomopathogenic fungi are amongst the most promising biological control agents for use against weevils affecting horticultural crops. Based on the 175 peer-reviewed studies we examined, it is clear that the success of weevil IPM programs relies on having detailed knowledge of the biology of the species involved. Three groups of life cycles based on the weevils' developmental habitats have been recognised in this study and the susceptibility of each group to EPF has been reviewed in the context of their possible pathways of exposure. The integration of EPF into both preventive and remedial aspects of IPM programs using the methods discussed in this review and targeting developmental stages in habitats that make them most vulnerable to EPF infection will help reduce dependence on synthetic insecticides for weevil management in many of the world's major horticultural crops.

Supplementary Materials: The following are available online at http://www.mdpi.com/2075-4450/11/10/659/s1. Figure S1: Flow diagram illustrating the selection process for publications include in this review. Figure S2: (A) The number of published studies using fungal entomopathogens on each weevil species affecting horticultural crops and included in this review, and (B) published studies using fungal entomopathogens for controlling weevils affecting horticultural crops and included in this review from 1973 to 2020.

Author Contributions: Conceptualisation, methodology, writing-review and editing, K.K.K., B.A.L.W., M.M.S., R.K.H., and G.J.A.; investigation, formal analysis, visualisation, and writing-original draft preparation, K.K.K. All authors have read and agreed to the published version of the manuscript. 
Funding: This study was supported by a postgraduate scholarship to the first author from the University of Southern Queensland and was partly funded by Hort Innovation Australia with the Australian macadamia industry's research and development levy and contributions from the Australian government (Grant No. MC16004).

Conflicts of Interest: The authors declare no conflict of interest.

\section{References}

1. Hill, D.S. The Economic Importance of Insects; Springer: London, UK, 1997; pp. 1-5.

2. Culliney, T.W. Chapter 8: Crop losses to arthropods. In Integrated Pest Management: Pesticide Problems; Pimentel, D., Peshin, R., Eds.; Springer: Dordrecht, The Netherlands, 2014; Volume 3, pp. 201-225.

3. Atwood, D.; Paisley-Jones, C. Pesticides Industry Sales and Usage: 2008-2012 Market Estimates; United States Environmental Protection Agency: Washington, DC, USA, 2017. Available online: https://www.epa.gov/sites/ production/files/2017-01/documents/pesticides-industry-sales-usage-2016_0.pdf (accessed on 16 July 2020).

4. Nicholas, A.H.; Spooner-Hart, R.N.; Vickers, R.A. Abundance and natural control of the woolly aphid Eriosoma lanigerum in an Australian apple orchard IPM program. Biocontrol 2005, 50, 271-291. [CrossRef]

5. Zalucki, M.P.; Adamson, D.; Furlong, M.J. The future of IPM: Whither or wither? Aust. J. Entomol. 2009, 48, 85-96. [CrossRef]

6. Dutcher, J.D. A review of resurgence and replacement causing pest outbreaks in IPM. In General Concepts in Integrated Pest and Disease Management; Ciancio, A., Mukerji, K.G., Eds.; Springer: Dordrecht, The Netherlands, 2007; pp. 27-43.

7. Pimentel, D.; Acquay, H.; Biltonen, M.; Rice, P.; Silva, M.; Nelson, J.; Lipner, V.; Giordano, S.; Horowitz, A.; D'Amore, M. Environmental and economic costs of pesticide use. Bioscience 1992, 42, 750-760. [CrossRef]

8. Pickering, J.; Dutcher, J.D.; Ekbom, B.S. The effect of a fungicide on fungal-induced mortality of pecan aphids (Homoptera: Aphididae) in the field. J. Econ. Entomol. 1990, 83, 1801-1805. [CrossRef]

9. Chandler, D.; Bailey, A.S.; Tatchell, G.M.; Davidson, G.; Greaves, J.; Grant, W.P. The development, regulation and use of biopesticides for integrated pest management. Philos. Trans. R. Soc. B 2011, 366, 1987-1998. [CrossRef]

10. Leahy, J.; Mendelsohn, M.; Kough, J.; Jones, R.; Berckes, N. Biopesticide oversight and registration at the US Environmental Protection Agency. In Biopesticides: State of the Art and Future Opportunities; Gross, A.D., Coats, J.R., Duke, S.O., Seiber, J.N., Eds.; ACS Publications: Washington, DC, USA, 2014; pp. 3-18.

11. Glare, T.; Caradus, J.; Gelernter, W.; Jackson, T.; Keyhani, N.; Köhl, J.; Marrone, P.; Morin, L.; Stewart, A. Have biopesticides come of age? Trends Biotechnol. 2012, 30, 250-258. [CrossRef]

12. Olson, S. An analysis of the biopesticide market now and where it is going. Outlooks Pest Manag. 2015, 26, 203-206. [CrossRef]

13. Dolinski, C.; Lacey, L.A. Microbial control of arthropod pests of tropical tree fruits. Neotrop. Entomol. 2007, 36, 161-179. [CrossRef]

14. Lacey, L.A.; Shapiro-Ilan, D.I. Microbial control of insect pests in temperate orchard systems: Potential for incorporation into IPM. Annu. Rev. Entomol. 2008, 53, 121-144. [CrossRef]

15. Lacey, L.A.; Grzywacz, D.; Shapiro-Ilan, D.I.; Frutos, R.; Brownbridge, M.; Goettel, M.S. Insect pathogens as biological control agents: Back to the future. J. Invertebr. Pathol. 2015, 132, 1-41. [CrossRef]

16. McKinnon, A.C.; Saari, S.; Moran-Diez, M.E.; Meyling, N.V.; Raad, M.; Glare, T.R. Beauveria bassiana as an endophyte: A critical review on associated methodology and biocontrol potential. Biocontrol 2017, 62, 1-17. [CrossRef]

17. Navarro-Llopis, V.; Ayala, I.; Sanchis, J.; Primo, J.; Moya, P. Field efficacy of a Metarhizium anisopliae-based attractant-contaminant device to control Ceratitis capitata (Diptera: Tephritidae). J. Econ. Entomol. 2015, 108, 1570-1578. [CrossRef] [PubMed]

18. Brandl, M.A.; Schumann, M.; Przyklenk, M.; Patel, A.; Vidal, S. Wireworm damage reduction in potatoes with an attract-and-kill strategy using Metarhizium brunneum. J. Pest Sci. 2017, 90, 479-493. [CrossRef]

19. Toledo, J.; Flores, S.; Campos, S.; Villaseñor, A.; Enkerlin, W.; Liedo, P.; Valle, Á.; Montoya, P. Pathogenicity of three formulations of Beauveria bassiana and efficacy of autoinoculation devices and sterile fruit fly males for dissemination of conidia for the control of Ceratitis capitata. Entomol. Exp. Appl. 2017, 164, 340-349. [CrossRef] 
20. Sookar, P.; Bhagwant, S.; Khayrattee, F.B.; Chooneea, Y.; Ekesi, S. Mating compatibility of wild and sterile melon flies, Bactrocera cucurbitae (Diptera: Tephritidae) treated with entomopathogenic fungi. J. Appl. Entomol. 2014, 138, 409-417. [CrossRef]

21. Novelo-Rincón, L.F.; Montoya, P.; Hernández-Ortiz, V.; Liedo, P.; Toledo, J. Mating performance of sterile Mexican fruit fly Anastrepha ludens (Dipt., Tephritidae) males used as vectors of Beauveria bassiana (Bals.) Vuill. J. Appl. Entomol. 2009, 133, 702-710. [CrossRef]

22. Rossoni, C.; Kassab, S.O.; Loureiro, E.D.; Pereira, F.F.; Costa, D.P.; Barbosa, R.H.; Zanuncio, J.C. Metarhizium anisopliae and Beauveria bassiana (Hypocreales: Clavicipitaceae) are compatible with Cotesia flavipes (Hymenoptera: Braconidae). Fla. Entomol. 2014, 97, 1794-1804. [CrossRef]

23. Labbé, R.M.; Gillespie, D.R.; Cloutier, C.; Brodeur, J. Compatibility of an entomopathogenic fungus with a predator and a parasitoid in the biological control of greenhouse whitefly. Biocontrol Sci. Technol. 2009, 19, 429-446. [CrossRef]

24. Al Mazra'awi, M.S.; Shipp, J.L.; Broadbent, A.B.; Kevan, P.G. Dissemination of Beauveria bassiana by honey bees (Hymenoptera: Apidae) for control of tarnished plant bug (Hemiptera: Miridae) on canola. Environ. Entomol. 2006, 35, 1569-1577. [CrossRef]

25. Wraight, S.P.; Ramos, M.E. Characterization of the synergistic interaction between Beauveria bassiana strain GHA and Bacillus thuringiensis morrisoni strain tenebrionis applied against Colorado potato beetle larvae. J. Invertebr. Pathol. 2017, 144, 47-57. [CrossRef]

26. Sayed, A.M.M.; Behle, R.W. Evaluating a dual microbial agent biopesticide with Bacillus thuringiensis var. kurstaki and Beauveria bassiana blastospores. Biocontrol Sci. Technol. 2017, 27, 461-474.

27. Duarte, R.T.; Gonçalves, K.C.; Espinosa, D.J.L.; Moreira, L.F.; De Bortoli, S.A.; Humber, R.A.; Polanczyk, R.A. Potential of entomopathogenic fungi as biological control agents of diamondback moth (Lepidoptera: Plutellidae) and compatibility with chemical insecticides. J. Econ. Entomol. 2016, 109, 594-601. [CrossRef] [PubMed]

28. Niassy, S.; Maniania, N.K.; Subramanian, S.; Gitonga, M.L.; Maranga, R.; Obonyo, A.B.; Ekesi, S. Compatibility of Metarhizium anisopliae isolate ICIPE 69 with agrochemicals used in French bean production. Int. J. Pest Manag. 2012, 58, 131-137. [CrossRef]

29. Ree, B.; Knutson, A.E.; Harris, M. Controlling the Pecan Weevil. Texas Extension E-343. 2005. Available online: http://gregg.agrilife.org/files/2011/09/controllingthepecanweevil_1.pdf (accessed on 16 July 2020).

30. Mulder, P.G.; Harris, M.K.; Grantham, R.A. Biology and management of the pecan weevil (Coleoptera: Curculionidae). J. Integr. Pest Manag. 2012, 3, A1-A9. [CrossRef]

31. Muniappan, R.; Shepard, B.M.; Carner, G.R.; Ooi, P.A.C. Arthropod Pests of Horticultural Crops in Tropical Asia; CABI: Wallingford, UK, 2012; pp. 52-134.

32. Infante, F.; Pérez, J.; Vega, F.E. Redirect research to control coffee pest. Nature 2012, 489, 502. [CrossRef] [PubMed]

33. Gullan, P.J.; Cranston, P.S. The Insects: An. Outline of Entomology, 5th ed.; John Wiley \& Sons: Oxford, UK, 2014; pp. 418-456.

34. Oberprieler, R.G.; Marvaldi, A.E.; Anderson, R.S. Weevils, weevils, weevils everywhere. Zootaxa 2007, 1668, 491-520. [CrossRef]

35. Benelli, G.; Meregalli, M.; Canale, A. Field observations on the mating behavior of Aclees sp. cf. foveatus Voss (Coleoptera: Curculionidae), an exotic pest noxious to fig orchards. J. Insect Behav. 2014, 27, 419-427.

36. Parra, L.; Mutis, A.; Ceballos, R.; Lizama, M.; Pardo, F.; Perich, F.; Quiroz, A. Volatiles released from Vaccinium corymbosum were attractive to Aegorhinus superciliosus (Coleoptera: Curculionidae) in an olfactometric bioassay. Environ. Entomol. 2009, 38, 781-789. [CrossRef]

37. Espinoza, J.; Urzúa, A.; Tampe, J.; Parra, L.; Quiroz, A. Repellent activity of the essential oil from the heartwood of Pilgerodendron uviferum (D. Don) Florin against Aegorhinus superciliosus (Coleoptera: Curculionidae). Molecules 2016, 21, 533. [CrossRef]

38. Szendrei, Z.; Averill, A.; Alborn, H.; Rodriguez-Saona, C. Identification and field evaluation of attractants for the cranberry weevil, Anthonomus musculus Say. J. Chem. Ecol. 2011, 37, 387-397. [CrossRef]

39. Alford, D.V. Pest of Fruit Crops: A Colour Handbook, 2nd ed.; CRC Press: Boca Raton, FL, USA, 2014; pp. 152-174. 
40. Cross, J.V.; Burgess, C.M. Strawberry fruit yield and quality responses to flower bud removal: A simulation of damage by strawberry blossom weevil (Anthonomus rubi). J. Hortic. Sci. Biotechnol. 1998, 73, 676-680. [CrossRef]

41. Cross, J.V.; Easterbrook, M.A.; Crook, A.M.; Crook, D.; Fitz Gerald, J.D.; Innocenzi, P.J.; Jay, C.N.; Solomon, M.G. Review: Natural enemies and biocontrol of pests of strawberry in northern and central Europe. Biocontrol Sci. Technol. 2001, 11, 165-216.

42. Jeger, M.; Bragard, C.; Caffier, D.; Candresse, T.; Chatzivassiliou, E.; Dehnen-Schmutz, K.; Gilioli, G.; Gregoire, J.C.; Miret, J.A.J.; Navarro, M.N.; et al. Pest categorisation of Anthonomus signatus. EFSA J. 2017, 15,4882 .

43. Pulakkatu-thodi, I.; Motomura-Wages, S.; Miyasaka, S. Evaluation of insecticides for the management of rough sweetpotato weevil, Blosyrus asellus (Coleoptera: Curculionidae) in Hawai'i island. Crop Prot. 2018, 114, 223-227.

44. Racette, G.; Chouinard, G.; Vincent, C.; Hill, S.B. Ecology and management of plum curculio, Conotrachelus nenuphar [Coleoptera: Curculionidae], in apple orchards. Phytoprotection 1992, 73, 85-100.

45. Leskey, T.C.; Wright, S.E. Monitoring plum curculio, Conotrachelus nenuphar (Coleoptera: Curculionidae), populations in apple and peach orchards in the mid-Atlantic. J. Econ. Entomol. 2004, 97, 79-88.

46. Da Rosa, J.M.; Boff, M.I.C.; Nunes, M.Z.; Agostinetto, L.; Boff, P. Damage caused by Conotrachelus psidii (Coleoptera: Curculionidae) to the fruits of feijoa (Acca sellowiana). Rev. Colomb. Entomol. 2015, 41, 12-17.

47. Del Valle, E.E.; Dolinski, C.; Barreto, E.L.S.; Souza, R.M.; Samuels, R.I. Efficacy of Heterorhabditis baujardi LPP7 (Nematoda: Rhabditida) applied in Galleria mellonella (Lepidoptera: Pyralidae) insect cadavers to Conotrachelus psidii, (Coleoptera: Curculionidae) larvae. Biocontrol Sci. Technol. 2008, 18, 33-41.

48. Rukazambuga, N.D.T.M.; Gold, C.S.; Gowen, S.R. Yield loss in East African highland banana (Musa spp., AAA-EA group) caused by the banana weevil, Cosmopolites sordidus Germar. Crop Prot. 1998, 17, 581-589.

49. Keesey, I.W.; Barrett, B.A. Seasonal occurrence and soil distribution of the lesser chestnut weevil, Curculio sayi (Coleoptera: Curculionidae) in Mid-Missouri. J. Kans. Entomol. Soc. 2008, 81, 345-354.

50. Paparatti, B.; Speranza, S. Biological control of chestnut weevil (Curculio elephas Gyll.; Coleoptera, Curculionidae) with the entomopathogen fungus Beauveria bassiana (Balsamo) Vuill. (Deuteromycotina, Hyphomycetes). In Proceedings of the 2nd International Symposium on Chestnut, Bordeaux, France, 19 October 1998; Salesses, G., Ed.; International Society for Horticultural Science: Leuven, Belgium, 1999; pp. 459-464.

51. Guidone, L.; Valentini, N.; Rolle, L.; Me, G.; Tavella, L. Early nut development as a resistance factor to the attacks of Curculio nucum (Coleoptera: Curculionidae). Ann. Appl. Biol. 2007, 150, 323-329. [CrossRef]

52. Batalla-Carrera, L.; Morton, A.; Garcia-del-Pino, F. Field efficacy against the hazelnut weevil, Curculio nucum and short-term persistence of entomopathogenic nematodes. Span. J. Agric. Res. 2013, 11, 1112-1119. [CrossRef]

53. Pelsue, F.W.; Zhang, R.Z. A review of the Genus Curculio from China with descriptions of fourteen new species. Part IV. The Curculio sikkimensis (Heller) group (Coleoptera: Curculionidae: Curculioninae: Curculionini). Coleopt. Bull. 2003, 57, 311-333. [CrossRef]

54. Kim, Y.J.; Yoon, C.M.; Shin, S.C.; Choi, K.S.; Kim, G.H. Seasonal occurrence of the larvae and adults of chestnut weevil, Curculio sikkimensis (Coleoptera: Curculionidae). Korean J. Appl. Entomol. 2008, 47, 9-15. [CrossRef]

55. Reddy, P.P. Plant Protection in Tropical Root and Tuber Crops; Springer: New Delhi, India, 2015; pp. 87-98.

56. Smit, N.E.J.M.; van Huis, A. Biology of the African sweetpotato weevil species Cylas puncticollis (Boheman) and C. brunneus (Fabricius) (Coleoptera: Apionidae). Int. J. Trop. Insect Sci. 1998, 18, 93-100. [CrossRef]

57. Weissling, T.J.; Peña, J.E.; Giblin-Davis, R.M.; Knapp, J.L., Jr. Diaprepes root weevil, Diaprepes abbreviatus (Linnaeus) (Insecta: Coleoptera: Curculionidae). IFAS Extension EENY-024. 2009. Available online: https://edis.ifas.ufl.edu/pdffiles/IN/IN15100.pdf (accessed on 16 July 2020).

58. Diaz, V.; Caicedo, A.M.; Carabali, A. Life cycle and morphological description of Heilipus lauri Boheman (Coleoptera: Curculionidae) in Colombia. Acta Zool. Mex. 2017, 33, 231-242.

59. Castañeda-Vildozola, Á.; Franco-Mora, O.; De Jesús Pérez-Lopez, D.; Nava-Díaz, C.; Carrasco, J.V.; Vargas-Rojas, L. Association of Heilipus lauri Boheman and Conotrachelus perseae Barber (Coleoptera: Curculionidae) on avocado in Mexico. Coleopt. Bull. 2013, 67, 116-118. [CrossRef] 
60. Oliveira, C.M.; Auad, A.M.; Mendes, S.M.; Frizzas, M.R. Economic impact of exotic insect pests in Brazilian agriculture. J. Appl. Entomol. 2013, 137, 1-15. [CrossRef]

61. Bright, J. Macadamia Seed Weevil (Kuschelorhynchus macadamiae) Orchard Management. Primefact 1585. 2017. Available online: https://www.dpi.nsw.gov.au/_data/assets/pdf_file/0008/731987/Macadamia-seedweevil-update-orchard-management_2.pdf (accessed on 16 July 2020).

62. Huwer, R. Ecology and Management of Sigastus Weevil in Macadamias; Horticulture Innovation Australia Limited: Sydney, Australia, 2016. Available online: https://www.horticulture.com.au/globalassets/laserfiche/ assets/project-reports/mc15010/mc15010-final-report-514.pdf (accessed on 16 July 2020).

63. Padmanaban, B.; Sathiamoorthy, S. The Banana Stem Weevil Odoiporus longicollis. Musa Pest Fact Sheet No. 5. 2001. Available online: https://www.bioversityinternational.org/fileadmin/_migrated/uploads/tx_news/ The_Banana_stem_weevil_Odoiporus_longicollis_756.pdf (accessed on 16 July 2020).

64. Moorhouse, E.R.; Charnley, A.K.; Gillespie, A.T. A review of the biology and control of the vine weevil, Otiorhynchus sulcatus (Coleoptera: Curculionidae). Ann. Appl. Biol. 1992, 121, 431-454. [CrossRef]

65. Prior, C.; Jollands, P.; Le Patourel, G. Infectivity of oil and water formulations of Beauveria bassiana (Deuteromycotina: Hyphomycetes) to the cocoa weevil pest Pantorhytes plutus (Coleoptera: Curculionidae). J. Invertebr. Pathol. 1988, 52, 66-72. [CrossRef]

66. Gressitt, J.L. The weevil genus Pantorhytes (Coleoptera) involving cacao pests and epizoic symbiosis with cryptogamic plants and microfauna. Pac. Insects 1966, 8, 915-965.

67. Ferreira, T.; Malan, A.P. Potential of entomopathogenic nematodes for the control of the banded fruit weevil, Phlyctinus callosus (Schönherr) (Coleoptera: Curculionidae). J. Helminthol. 2014, 88, 293-301. [CrossRef] [PubMed]

68. Witt, A.B.R.; Little, R.M.; Crowe, T.M. The effectiveness of helmeted guineafowl Numida meleagris (Linnaeus 1766) in controlling the banded fruit weevil Phlyctinus callosus (Schönherr 1826), and their impact on other invertebrates in apple orchards in the Western Cape Province, South Africa. Agric. Ecosyst. Environ. 1995, 55, 169-179. [CrossRef]

69. Seybold, S.J.; Coleman, T.W.; Dallara, P.L.; Dart, N.L.; Graves, A.D.; Pederson, L.A.; Spichiger, S.E. Recent collecting reveals new state records and geographic extremes in the distribution of the walnut twig beetle, Pityophthorus juglandis Blackman (Coleoptera: Scolytidae), in the United States. Pan-Pac. Entomol. 2012, 88, 277-280. [CrossRef]

70. Wattanapongsiri, A. A Revision to the Genera Rhynchophorus and Dynamis (Coleoptera: Curculionidae). Ph.D. Thesis, Oregon State University, Corvallis, OR, USA, 1965.

71. Faleiro, J.R. A review of the issues and management of the red palm weevil Rhynchophorus ferrugineus (Coleoptera: Rhynchophoridae) in coconut and date palm during the last one hundred years. Int. J. Trop. Insect Sci. 2006, 26, 135-154.

72. El-Sabea, A.M.R.; Faleiro, J.R.; Abo-El-Saad, M.M. The threat of red palm weevil Rhynchophorus ferrugineus to date plantations of the Gulf region in the Middle-East: An economic perspective. Outlooks Pest Manag. 2009, 20, 131-134. [CrossRef]

73. Oehlschlager, A.C.; Chinchilla, C.; Castillo, G.; Gonzalez, L. Control of red ring disease by mass trapping of Rhynchophorus palmarum (Coleoptera: Curculionidae). Fla. Entomol. 2002, 85, 507-513. [CrossRef]

74. Chang, V.C.S. Macadamia quick decline and Xyleborus beetles (Coleoptera: Scolytidae). Int. J. Pest Manag. 1993, 39, 144-148. [CrossRef]

75. Lona, I.D.; Miller, D.G., III; Hatfield, C.A.; Rosecrance, R.C.; Nelson, L.J.; Audley, J.P.; Siefker, M.A.; Chen, Y.; Seybold, S.J. Host selection behavior mediated by differential landing rates of the walnut twig beetle, Pityophthorus juglandis, and associated subcortical insect species, on two western North American walnut species, Juglans californica and J. major. Entomol. Exp. Appl. 2020, 168, 240-258. [CrossRef]

76. Castrejón-Antonio, J.E.; Tamez-Guerra, P.; Montesinos-Matias, R.; Ek-Ramos, M.J.; Garza-López, P.M.; Arredondo-Bernal, H.C. Selection of Beauveria bassiana (Hypocreales: Cordycipitaceae) strains to control Xyleborus affinis (Curculionidae: Scolytinae) females. PeerJ 2020, 8, e9472. [CrossRef]

77. Mailloux, G.; Bostanian, N.J. Development of the strawberry bud weevil (Coleoptera: Curculionidae) in strawberry fields. Ann. Entomol. Soc Am. 1993, 86, 384-393. [CrossRef]

78. Eaton, A.T. Plum Curculio. UNH Cooperative Extension. 2018. Available online: https://extension.unh.edu/ resources/files/Resource002799_Rep4154.pdf (accessed on 16 July 2020). 
79. Bailez, O.E.; Viana-Bailez, A.M.; de Lima, J.O.G.; Moreira, D.D.O. Life-history of the guava weevil, Conotrachelus psidii Marshall (Coleoptera: Curculionidae), under laboratory conditions. Neotrop. Entomol. 2003, 32, 203-207. [CrossRef]

80. Hill, D.S. Pests of Crops in Warmer Climates and Their Control; Springer: London, UK, 2008; p. 329.

81. Cottrell, T.E.; Wood, B.W. Movement of adult pecan weevils Curculio caryae within pecan orchards. Agric. For. Entomol. 2008, 10, 363-373. [CrossRef]

82. Venette, R.; Davis, E.; Heisler, H.; Larson, M. Mini Risk Assessment, Chestnut Weevil, Curculio elephas (Gyllenhal), [Coleoptera: Curculionidae]. 2003. Available online: http://download.ceris.purdue.edu/file/336 (accessed on 16 July 2020).

83. Tuncer, C.; Ecevit, O. Current status of hazelnut pests in Turkey. In Proceedings of the 4th International Symposium on Hazelnut, Ordu, Turkey, 30 July 1996; Köksal, A.I., Okay, Y., Günes, N.T., Eds.; International Society for Horticultural Science: Leuven, Belgium, 1997; pp. 545-552.

84. Grafton-Cardwell, E.; Godfrey, K.; Peña, J.; McCoy, C.; Luck, R. Diaprepes Root Weevil. ANR Publication 8131. 2004. Available online: https://ucanr.edu/datastoreFiles/391-265.pdf (accessed on 16 July 2020).

85. Damon, A. A review of the biology and control of the coffee berry borer, Hypothenemus hampei (Coleoptera: Scolytidae). Bull. Entomol. Res. 2000, 90, 453-465. [CrossRef] [PubMed]

86. Bright, J. Sigastus Weevil Update. Part 1. Life Cycle and Monitoring Keys to Control; Australian Macadamia Society Ltd.: Lismore, Australia, 2017. Available online: https:/www.horticulture.com.au/globalassets/hortinnovation/resource-assets/mc-ipm-program-sigastus-weevil-fact-sheet.pdf (accessed on 16 July 2020).

87. Prabhavathi, M.K.; Ghosh, S.K. Studies on the interaction between Odoiporous longicollis and endophytic Beauveria bassiana by establishing fungal infection to bsw in the plant system. Int. J. Plant Prot. 2014, 7, 312-317. [CrossRef]

88. Tsatsia, H.; Jackson, G. Cocoa Weevil Borer. Available online: http://www.pestnet.org/fact_sheets/cocoa_ weevil_borer_061.htm (accessed on 23 May 2018).

89. Dlamini, B.E.; Addison, P.; Malan, A.P. A review of the biology and control of Phlyctinus callosus (Schönherr) (Coleoptera: Curculionidae), with special reference to biological control using entomopathogenic nematodes and fungi. Afr. Entomol. 2019, 27, 279-288. [CrossRef]

90. Mayfield, A.E.; Juzwik, J.; Scholer, J.; Vandenberg, J.D.; Taylor, A. Effect of bark application with Beauveria bassiana and permethrin insecticide on the walnut twig beetle (Coleoptera: Curculionidae) in black walnut bolts. J. Econ. Entomol. 2019, 112, 2493-2496. [CrossRef]

91. Mendel, Z.; Ben-Yehuda, S.; Marcus, R.; Nestel, D. Distribution and extent of damage by Scolytus spp. to stone and pome fruit orchards in Israel. Int. J. Trop. Insect Sci. 1997, 17, 175-181. [CrossRef]

92. Gargani, E.; Mazza, G.; Benvenuti, C.; Torrini, G.; Strangi, A.; Pennacchio, F.; Roversi, P.F. Biological control of Aclees sp. cf. foveatus and first recovery of an associate Beauveria bassiana strain. Redia 2016, 99, $29-33$.

93. Sabbahi, R.; Merzouki, A.; Guertin, C. Efficacy of Beauveria bassiana against the strawberry pests, Lygus lineolaris, Anthonomus signatus and Otiorhynchus ovatus. J. Appl. Entomol. 2008, 132, 151-160. [CrossRef]

94. Lopes, R.B.; Michereff-Filho, M.; Tigano, M.S.; Neves, P.M.O.J.; López, E.L.; Fancelli, M.; da Silva, J.P. Virulence and horizontal transmission of selected Brazilian strains of Beauveria bassiana against Cosmopolites sordidus under laboratory conditions. Bull. Insectol. 2011, 64, 201-208.

95. Lopes, R.B.; Mesquita, A.L.M.; Tigano, M.S.; Souza, D.A.; Martins, I.; Faria, M. Diversity of indigenous Beauveria and Metarhizium spp. in a commercial banana field and their virulence toward Cosmopolites sordidus (Coleoptera: Curculionidae). Fungal Ecol. 2013, 6, 356-364. [CrossRef]

96. Fancelli, M.; Dias, A.B.; Delalibera, I.; de Jesus, S.C.; do Nascimento, A.S.; de Oliveira e Silva, S.; Caldas, R.C.; Ledo, C.A.S. Beauveria bassiana strains for biological control of Cosmopolites sordidus (Germ.) (Coleoptera: Curculionidae) in plantain. Biomed Res. Int. 2013, 2013, 184756. [CrossRef] [PubMed]

97. González, D.N.; Chávez, M.A.A.; Gutiérrez, R.L.; Cupul, W.C.; Ochoa, J.M.; Velasco, E.G. Suitability of Cordyceps bassiana and Metarhizium anisopliae for biological control of Cosmopolites sordidus (Germar) (Coleoptera: Curculionidae) in an organic Mexican banana plantation: Laboratory and field trials. J. Plant Dis. Prot. 2018, 125, 73-81. [CrossRef]

98. Omukoko, C.A.; Maniania, K.N.; Wesonga, J.M.; Kahangi, E.M.; Wamocho, L.S. Pathogenicity of isolates of beauveria bassiana to the banana weevil Cosmopolites sordidus. J. Agric. Sci. Technol. 2011, 13, 3-14.

99. Omukoko, C.A.; Maniania, K.N.; Wesonga, J.M.; Kahangi, E.M.; Wamocho, L.S. Virulence of three strains of Beauveria bassiana against the banana weevil. J. Agric. Biol. Sci. 2014, 9, 333-336. 
100. Omukoko, C.A.; Wesonga, J.M.; Maniania, K.N.; Kahangi, E.M.; Wamocho, L.S. Screening of Beauveria bassiana isolates to the banana weevil and horizontal transmission under laboratory conditions. J. Agric. Sci. Technol. 2014, 16, 1-12.

101. Maharaj, K.; Khan, A. Efficacy of banana spray oil, mineral oil and water formulations of Beauveria bassiana Balsamo for the control of Cosmopolites sordidus Germar (Coleoptera: Curculionidae) in Musa spp. Int. J. Trop. Agric. 2016, 34, 1455-1460.

102. Membang, G.; Ambang, Z.; Mahot, H.C.; Kuate, A.F.; Fiaboe, K.K.M.; Hanna, R. Cosmopolites sordidus (Germar) susceptibility to indigenous Cameroonian Beauveria bassiana (Bals.) Vuill. and Metarhizium anisopliae (Metsch.) isolates. J. Appl. Entomol. 2020, 144, 468-480. [CrossRef]

103. Dotaona, R.; Wilson, B.A.L.; Stevens, M.M.; Holloway, J.; Ash, G.J. Screening of tropical isolates of Metarhizium anisopliae (Hypocreales: Clavicipitaceae) for virulence to the sweetpotato weevil, Cylas formicarius (Coleoptera: Brentidae). Int. J. Trop. Insect Sci. 2015, 35, 153-163. [CrossRef]

104. Saputro, T.B.; Prayogo, Y.; Rohman, F.L.; Alami, N.H. The virulence improvement of Beauveria bassiana in infecting Cylas formicarius modulated by various chitin based compounds. Biodiversitas 2019, 20, 2486-2493. [CrossRef]

105. Ondiaka, S.; Maniania, N.K.; Nyamasyo, G.H.N.; Nderitu, J.H. Virulence of the entomopathogenic fungi Beauveria bassiana and Metarhizium anisopliae to sweetpotato weevil Cylas puncticollis and effects on fecundity and egg viability. Ann. Appl. Biol. 2008, 153, 41-48. [CrossRef]

106. Clavijo, A.P.; Holguin, C.M. Pathogenicity of commercial entomopathogenic fungal strains on the avocado seed borer (ASB), Heilipus lauri (Coleoptera: Curculionidae) under laboratory conditions. Int. J. Trop. Insect Sci. 2020. [CrossRef]

107. De la Rosa-Reyes, W.; Godinez-Aguilar, J.L.; Alatorre-Rosas, R. Biological activity of five strains of Metarhizium anisopliae, upon the coffee berry borer Hypothenemus hampei (Col.: Scolytidae). Entomophaga 1995, 40, 403-412. [CrossRef]

108. De la Rosa, W.; Alatorre, R.; Trujillo, J.; Barrera, J.F. Virulence of Beauveria bassiana (Deuteromycetes) strains against the coffee berry borer (Coleoptera: Scolytidae). J. Econ. Entomol. 1997, 90, 1534-1538. [CrossRef]

109. Haraprasad, N.; Niranjana, S.R.; Prakash, H.S.; Shetty, H.S.; Wahab, S. Beauveria bassiana-A potential mycopesticide for the efficient control of coffee berry borer, Hypothenemus hampei (Ferrari) in India. Biocontrol Sci. Technol. 2001, 11, 251-260. [CrossRef]

110. Pava-Ripoll, M.; Posada, F.J.; Momen, B.; Wang, C.; St. Leger, R.J. Increased pathogenicity against coffee berry borer, Hypothenemus hampei (Coleoptera: Curculionidae) by Metarhizium anisopliae expressing the scorpion toxin (AaIT) gene. J. Invertebr. Pathol. 2008, 99, 220-226. [CrossRef]

111. Samuels, R.I.; Pereira, R.C.; Gava, C.A.T. Infection of the coffee berry borer Hypothenemus hampei (Coleoptera: Scolytidae) by Brazilian isolates of the entomopathogenic fungi Beauveria bassiana and Metarhizium anisopliae (Deuteromycotina: Hyphomycetes). Biocontrol Sci. Technol. 2002, 12, 631-635. [CrossRef]

112. Varela, A.; Morales, E. Characterization of some Beauveria bassiana isolates and their virulence toward the coffee berry borer Hypothenemus hampei. J. Invertebr. Pathol. 1996, 67, 147-152. [CrossRef]

113. Vera, J.T.; Montoya, E.C.; Benavides, P.; Góngora, C.E. Evaluation of Beauveria bassiana (Ascomycota: Hypocreales) as a control of the coffee berry borer Hypothenemus hampei (Coleoptera: Curculionidae: Scolytinae) emerging from fallen, infested coffee berries on the ground. Biocontrol Sci. Technol. 2011, 21, 1-14. [CrossRef]

114. Cruz, L.P.; Gaitan, A.L.; Gongora, C.E. Exploiting the genetic diversity of Beauveria bassiana for improving the biological control of the coffee berry borer through the use of strain mixtures. Appl. Microbiol. Biotechnol. 2006, 71, 918-926. [CrossRef] [PubMed]

115. Mota, L.H.C.; Silva, W.D.; Sermarini, R.A.; Demétrio, C.G.B.; Bento, J.M.S.; Delalibera, I. Autoinoculation trap for management of Hypothenemus hampei (Ferrari) with Beauveria bassiana (Bals.) in coffee crops. Biol. Control 2017, 111, 32-39. [CrossRef]

116. Posada-Flórez, F.J. Production of Beauveria bassiana fungal spores on rice to control the coffee berry borer, Hypothenemus hampei, in Colombia. J. Insect Sci. 2008, 8, 41. [CrossRef]

117. Balakrishnan, M.M.; Prakash, R.N. Infectivity of ten Metarhizium anisopliae isolates to the coffee berry borer Hypothenemus hampei (Coleoptera: Curculionidae). J. Entomol. Zool. Stud. 2014, 2, 246-249. 
118. Belay, Y.C.; Tenkegna, T.A. Bioassay and pilot mass production of entomopathogenic fungus, Beauveria bassiana for the control of coffee berry borer (Hypothenemus hampei: Scolytidae), Ferrari. J. Appl. Biosci. 2017, $117,11669-11683$.

119. Khun, K.K.; Ash, G.J.; Stevens, M.M.; Huwer, R.K.; Wilson, B.A.L. Response of the macadamia seed weevil Kuschelorhynchus macadamiae (Coleoptera: Curculionidae) to Metarhizium anisopliae and Beauveria bassiana in laboratory bioassays. J. Invertebr. Pathol. 2020, 174, 107437. [CrossRef] [PubMed]

120. Padmanaban, B.; Thangavelu, R.; Gopi, M.; Mustaffa, M.M. Effect of mass multiplication media on sporulation, field efficacy and shelf life of Beauveria bassiana against rhizome and pseudostem weevils of banana. J. Biol. Control 2009, 23, 277-283.

121. Alagesan, A.; Padmanaban, B.; Tharani, G.; Jawahar, S.; Manivannan, S. An assessment of biological control of the banana pseudostem weevil Odoiporus longicollis (Olivier) by entomopathogenic fungi Beauveria bassiana. Biocatal. Agric. Biotechnol. 2019, 20, 101262. [CrossRef]

122. Awasthi, N.S.; Sridharan, S.; Mohankumar, S. In vitro evaluation of native isolate of Metarhizium anisopliae (Metchinkoff) Sorokin and its oil in water formulations against Odoiporus longicollis Olivier. J. Biol. Control 2017, 31, 248-252. [CrossRef]

123. Castrillo, L.A.; Mayfield, A.E.; Griggs, M.H.; Camp, R.; Mudder, B.; Taylor, A.; Vandenberg, J.D. Mortality and reduced brood production in walnut twig beetles, Pityophthorus juglandis (Coleoptera: Curculionidae), following exposure to commercial strains of entomopathogenic fungi Beauveria bassiana and Metarhizium brunneum. Biol. Control 2017, 114, 79-86. [CrossRef]

124. Abdel-Samad, S.S.M.; Mahmoud, B.A.; Abbas, M.S.T. Evaluation of the fungus, Beauveria bassiana (Bals.) Vuill as a bio-control agent against the red palm weevil, Rhynchophorus ferrugineus (Oliv.) (Coleoptera: Curculionidae). Egypt J. Biol. Pest Control 2011, 21, 125-129.

125. Dembilio, Ó.; Quesada-Moraga, E.; Santiago-Álvarez, C.; Jacas, J.A. Potential of an indigenous strain of the entomopathogenic fungus Beauveria bassiana as a biological control agent against the red palm weevil, Rhynchophorus ferrugineus. J. Invertebr. Pathol. 2010, 104, 214-221. [CrossRef] [PubMed]

126. Gindin, G.; Levski, S.; Glazer, I.; Soroker, V. Evaluation of the entomopathogenic fungi Metarhizium anisopliae and Beauveria bassiana against the red palm weevil Rhynchophorus ferrugineus. Phytoparasitica 2006, 34, 370-379. [CrossRef]

127. Hajjar, M.J.; Ajlan, A.M.; Al-Ahmad, M.H. New approach of Beauveria bassiana to control the red palm weevil (Coleoptera: Curculionidae) by trapping technique. J. Econ. Entomol. 2015, 108, 425-432. [CrossRef] [PubMed]

128. Hussain, A.; Rizwan-ul-Haq, M.; Al-Ayedh, H.; Ahmed, S.; Al-Jabr, A.M. Effect of Beauveria bassiana infection on the feeding performance and antioxidant defence of red palm weevil, Rhynchophorus ferrugineus. Biocontrol 2015, 60, 849-859. [CrossRef]

129. Hussain, A.; Rizwan-ul-Haq, M.; Al-Ayedh, H.; AlJabr, A.M. Susceptibility and immune defence mechanisms of Rhynchophorus ferrugineus (Olivier) (Coleoptera: Curculionidae) against entomopathogenic fungal infections. Int. J. Mol. Sci. 2016, 17, 1518. [CrossRef] [PubMed]

130. Lo Verde, G.; Torta, L.; Mondello, V.; Caldarella, C.G.; Burruano, S.; Caleca, V. Pathogenicity bioassays of isolates of Beauveria bassiana on Rhynchophorus ferrugineus. Pest Manag. Sci. 2015, 71, 323-328. [CrossRef]

131. Merghem, A. Susceptibility of the red palm weevil, Rhynchophorus ferrugineus (Olivier) to the green muscardine fungus, Metarhizium anisopliae (Metsch.) in the laboratory and in palm trees orchards. Egypt J. Biol. Pest Control 2011, 21, 179-183.

132. Ricaño, J.; Güerri-Agulló, B.; Serna-Sarriás, M.J.; Rubio-Llorca, G.; Asensio, L.; Barranco, P.; Lopez-Llorca, L.V. Evaluation of the pathogenicity of multiple isolates of Beauveria bassiana (Hypocreales: Clavicipitaceae) on Rhynchophorus ferrugineus (Coleoptera: Dryophthoridae) for the assessment of a solid formulation under simulated field conditions. Fla. Entomol. 2013, 96, 1311-1324. [CrossRef]

133. Sun, X.D.; Yan, W.; Qin, W.Q.; Zhang, J.; Niu, X.Q.; Ma, G.C.; Li, F.H. Screening of tropical isolates of Metarhizium anisopliae for virulence to the red palm weevil Rhynchophorus ferrugineus Olivier (Coleoptera: Curculionidae). SpringerPlus 2016, 5, 1100. [CrossRef]

134. Yasin, M.; Wakil, W.; Ghazanfar, M.U.; Qayyum, M.A.; Tahir, M.; Bedford, G.O. Virulence of entomopathogenic fungi Beauveria bassiana and Metarhizium anisopliae against red palm weevil, Rhynchophorus ferrugineus (Olivier). Entomol. Res. 2019, 49, 3-12. [CrossRef] 
135. El Husseini, M.M. Efficacy of the fungus Beauveria bassiana (Balsamo) Vuillemin on the red palm weevil Rhynchophorus ferrugineus Olivier (Coleoptera: Curculionidae) larvae and adults under laboratory conditions. Egypt J. Biol. Pest Control 2019, 29, 58. [CrossRef]

136. Abdel-Raheem, M.A.; Alghamdi, H.A.; Reyad, N.F. Virulence of fungal spores and silver nanoparticles from entomopathogenic fungi on the red palm weevil, Rhynchophorus ferrugineus Olivier (Coleoptera: Curculionidae). Egypt J. Biol. Pest Control 2019, 29, 97. [CrossRef]

137. Aldossary, A.A.; Shehata, S.T.; Hegazy, G.; Salem, M.A.; Faiza, M.A.M. Assessment of the entomopathogenic fungus Beauveria bassiana Saudi Arabian isolate (B-SA3) against the developmental stages of the red palm weevil, Rhynchophorus ferrugineus (Oliv.). Arab Univ. J. Agric. Sci. 2009, 17, 227-237.

138. Hou, F.J.; Addis, S.N.K.; Azmi, W.A. Virulence evaluation of entomopathogenic fungi against the red palm weevil, Rhynchophorus ferrugineus (Coleoptera: Dryopthoridae). Malays. Appl. Biol. 2018, 47, 25-30.

139. Qayyum, M.A.; Saleem, M.A.; Saeed, S.; Wakil, W.; Ishtiaq, M.; Ashraf, W.; Ahmed, N.; Ali, M.; Ikram, R.M.; Yasin, M.; et al. Integration of entomopathogenic fungi and eco-friendly insecticides for management of red palm weevil, Rhynchophorus ferrugineus (Olivier). Saudi J. Biol. Sci. 2020, 27, 1811-1817. [CrossRef]

140. Abdel-Raheem, M.A.; Reyad, N.F.; Alghamdi, H.A. Virulence of nanoparticle preparation of entomopathogenic fungi and entomopathogenic bacteria against red palm weevil Rhynchophorus ferrugineus (Olivier) (Coleoptera: Curculionidae). Rom. Biotechnol. Lett. 2020, 25, 1151-1159. [CrossRef]

141. Ishak, I.; Ng, L.C.; Haris-Hussain, M.; Jalinas, J.; Idris, A.B.; Azlina, Z.; Samsudin, A.; Wahizatul, A.A. Pathogenicity of an indigenous strain of the entomopathogenic fungus Metarhizium anisopliae (Hypocreales: Clavicipitaceae) (MET-GRA4 Strain) as a potential biological control agent against the red palm weevil (Coleoptera: Dryophthoridae). J. Econ. Entomol. 2020, 113, 43-49. [CrossRef]

142. Cheong, J.L.; Azmi, W.A. Dataset on the influence of relative humidity on the pathogenicity of Metarhizium anisopliae isolates from Thailand and Malaysia against red palm weevil (Rhynchophorus ferrugineus, Olivier) adult. Data Brief 2020, 30, 105482. [CrossRef]

143. Al-Keridis, L.A.; Gaber, N.M.; Aldawood, A.S. Pathogenicity of Saudi Arabian fungal isolates against egg and larval stages of Rhynchophorus ferrugineus under laboratory conditions. Int. J. Trop. Insect Sci. 2020. [CrossRef]

144. Batta, Y.A. Biocontrol of almond bark beetle (Scolytus amygdali Geurin-Meneville, Coleoptera: Scolytidae) using Beauveria bassiana (Bals.) Vuill. (Deuteromycotina: Hyphomycetes). J. Appl. Microbiol. 2007, 103, 1406-1414. [CrossRef] [PubMed]

145. Kaaya, G.P.; Seshu-Reddy, K.V.; Kokwaro, E.D.; Munyinyi, D.M. Pathogenicity of Beauveria bassiana, Metarhizium anisopliae and Serratia marcescens to the banana weevil Cosmopolites sordidus. Biocontrol Sci. Technol. 1993, 3, 177-187. [CrossRef]

146. Magara, E.; Nankinga, C.M.K.; Gold, C.S.; Kyamanywa, S.; Ragama, P.; Tushemereirwe, W.K.; Moore, D.; Gowen, S.R. Efficacy of Beauveria bassiana substrates and formulations for the control of banana weevil. Uganda J. Agric. Sci. 2004, 9, 900-905.

147. Francardi, V.; Benvenuti, C.; Roversi, P.F.; Rumine, P.; Barzanti, G. Entomopathogenicity of Beauveria bassiana (Bals.) Vuill. and Metarhizium anisopliae (Metsch.) Sorokin isolated from different sources in the control of Rhynchophorus ferrugineus (Oliver) (Coleoptera Curculionidae). Redia 2012, 95, 49-55.

148. Francardi, V.; Benvenuti, C.; Barzanti, G.P.; Roversi, P.F. Autocontamination trap with entomopathogenic fungi: A possible strategy in the control of Rhynchophorus ferrugineus (Olivier) (Coleoptera Curculionidae). Redia 2013, 96, 57-67.

149. Francardi, V.; Benvenuti, C.; Barzanti, G.P.; Roversi, P.F. Metarhizium anisopliae biopesticides and fungus isolates: Control efficacy against Rhynchophorus ferrugineus (Olivier) (Coleoptera Dryophthoridae) on different contamination substrata. Redia 2015, 98, 25-29.

150. Cito, A.; Mazza, G.; Strangi, A.; Benvenuti, C.; Barzanti, G.P.; Dreassi, E.; Turchetti, T.; Francardi, V.; Roversi, P.F. Characterization and comparison of Metarhizium strains isolated from Rhynchophorus ferrugineus. FEMS Microbiol. Lett. 2014, 355, 108-115. [CrossRef]

151. Peña, J.E.; Gilbin-Davis, R.M.; Duncan, R. Impact of indigenous Beauveria bassiana (Balsamo) Vuillemin on banana weevil and rotten sugarcane weevil (Coleoptera: Curculionidae) populations in banana in Florida. J. Agric. Entomol. 1995, 12, 163-167. 
152. Monzón, A.J.; Guharay, F.; Klingen, I. Natural occurrence of Beauveria bassiana in Hypothenemus hampei (Coleoptera: Curculionidae) populations in unsprayed coffee fields. J. Invertebr. Pathol. 2008, 97, 134-141. [CrossRef]

153. Wraight, S.P.; Galaini-Wraight, S.; Howes, R.L.; Castrillo, L.A.; Carruthers, R.I.; Smith, R.H.; Matsumoto, T.K.; Keith, L.M. Prevalence of naturally-occurring strains of Beauveria bassiana in populations of coffee berry borer Hypothenemus hampei on Hawai'i Island, with observations on coffee plant-H. hampei-B. bassiana interactions. J. Invertebr. Pathol. 2018, 156, 54-72. [CrossRef]

154. Asiry, K.A.; Sulieman, A.M.E.; Al-Anazi, N.A.; Veettil, V.N.; Abdelgadir, M.; Alkhregi, I. Isolation, phenotypic and genotypic characterization of indigenous Beauveria bassiana isolates from date palm infested with Rhynchophorus ferrugineus in Hail region, Saudi Arabia. Biosci. Biotechnol. Res. Commun. 2018, 11, $393-401$. [CrossRef]

155. Güerri-Agulló, B.; López-Follana, R.; Asensio, L.; Barranco, P.; Lopez-Llorca, L.V. Use of a solid formulation of Beauveria bassiana for biocontrol of the red palm weevil (Rhynchophorus ferrugineus) (Coleoptera: Dryophthoridae) under field conditions in SE Spain. Fla. Entomol. 2011, 94, 737-747. [CrossRef]

156. Prior, C.; Arura, M. The infectivity of Metarhizium anisopliae to two insect pests of coconuts. J. Invertebr. Pathol. 1985, 45, 187-194. [CrossRef]

157. Sabbahi, R.; Merzouki, A.; Guertin, C. Potential effect of Beauveria bassiana (Hypocreales: Clavicipitaceae) on Anthonomus signatus (Coleoptera: Curculionidae) in strawberries. Biocontrol Sci. Technol. 2009, 19, 729-741. [CrossRef]

158. Schoeman, P.S.; Botha, H. Field management of the banana weevil, Cosmopolites sordidus (Coleoptera: Curculionidae), with Beauveria bassiana. Afr. Plant Prot. 2003, 9, 1-3.

159. Hlerema, I.; Laurie, S.; Eiasu, B. Preliminary observations on use of Beauveria bassiana for the control of the sweetpotato weevil (Cylas sp.) in South Africa. Open Agric. 2017, 2, 595-599.

160. de la Rosa, W.; Alatorre, R.; Barrera, J.F.; Toriello, C. Effect of Beauveria bassiana and Metarhizium anisopliae (Deuteromycetes) upon the coffee berry borer (Coleoptera: Scolytidae) under field conditions. J. Econ. Entomol. 2000, 93, 1409-1414. [CrossRef]

161. Edgington, S.; Segura, H.; de la Rosa, W.; Williams, T. Photoprotection of Beauveria bassiana: Testing simple formulations for control of the coffee berry borer. Int. J. Pest Manag. 2000, 46, 169-176. [CrossRef]

162. Greco, E.B.; Wright, M.G.; Burgueño, J.; Jaronski, S.T. Efficacy of Beauveria bassiana applications on coffee berry borer across an elevation gradient in Hawaii. Biocontrol Sci. Technol. 2018, 28, 995-1013. [CrossRef]

163. Hollingsworth, R.G.; Aristizábal, L.F.; Shriner, S.; Mascarin, G.M.; Moral, R.D.; Arthurs, S.P. Incorporating Beauveria bassiana into an integrated pest management plan for coffee berry borer in Hawaii. Front. Sustain. Food Syst. 2020, 4, 22. [CrossRef]

164. El-Sufty, R.; Al-Awash, S.A.; Al Bgham, S.; Shahdad, A.S.; Al Bathra, A.H. Pathogenicity of the fungus Beauveria bassiana (Bals.) Vuill to the red palm weevil, Rhynchophorus ferrugineus (Oliv.) (Col.: Curculionidae) under laboratory and field conditions. Egypt J. Biol. Pest Control 2009, 19, 81-85.

165. Sewify, G.H.; Belal, M.H.; Al-Awash, S.A. Use of the entomopathogenic fungus, Beauveria bassiana for the biological control of the red palm weevil, Rhynchophorus ferrugineus Olivier. Egypt J. Biol. Pest Control 2009, 19, 157-163.

166. Su, C.Y.; Tzean, S.S.; Ko, W.H. Beauveria bassiana as the lethal factor in a Taiwanese soil pernicious to sweetpotato weevil, Cylas formicarius. J. Invertebr. Pathol. 1988, 52, 195-197. [CrossRef]

167. Nankinga, C.M.; Moore, D. Reduction of banana weevil populations using different formulations of the entomopathogenic fungus Beauveria bassiana. Biocontrol Sci. Technol. 2000, 10, 645-657. [CrossRef]

168. Godonou, I.; Green, K.R.; Oduro, K.A.; Lomer, C.J.; Afreh-Nuamah, K. Field evaluation of selected formulations of Beauveria bassiana for the management of the banana weevil (Cosmopolites sordidus) on plantain (Musa spp., AAB group). Biocontrol Sci. Technol. 2000, 10, 779-788. [CrossRef]

169. Bustillo, A.E.; Bernal, M.G.; Benavides, P.; Chaves, B. Dynamics of Beauveria bassiana and Metarhizium anisopliae infecting Hypothenemus hampei (Coleoptera: Scolytidae) populations emerging from fallen coffee berries. Fla. Entomol. 1999, 82, 491-498. [CrossRef]

170. Malik, M.A.; Ahmad, S.J.N.; Ahmad, J.N.; Abbasi, A.; Sufyan, M.; Arif, M.J. Efficacy of Bacillus thuringiensis and Beauveria bassiana against red palm weevil Rhynchophorus ferrugineus Olivier (Coleoptera: Curculionidae). Afr. Entomol. 2019, 27, 386-394. [CrossRef] 
171. Saleh, M.M.E.; Hegazy, G.; Salem, M.; Hanounik, S.B.; Al Mohanna, O.; Alheji, M.A. Persistence of Steinernema carpocapsae (Nematoda: Steinernematidae) and Beauveria bassiana (Deuteromycotina: Hyphomycetes) in soil around date palm trunks and their effect on adults of Rhynchophorus ferrugineus. Egypt J. Biol. Pest Control 2004, 14, 141-145.

172. Wakil, W.; Yasin, M.; Shapiro-Ilan, D.I. Effects of single and combined applications of entomopathogenic fungi and nematodes against Rhynchophorus ferrugineus (Olivier). Sci. Rep. 2017, 7, 5971. [CrossRef]

173. Tinzaara, W.; Gold, C.S.; Dicke, M.; Van Huis, A.; Nankinga, C.M.; Kagezi, G.H.; Ragama, P.E. The use of aggregation pheromone to enhance dissemination of Beauveria bassiana for the control of the banana weevil in Uganda. Biocontrol Sci. Technol. 2007, 17, 111-124. [CrossRef]

174. Lopes, R.B.; Laumann, R.A.; Moore, D.; Oliveira, M.W.M.; Faria, M. Combination of the fungus Beauveria bassiana and pheromone in an attract-and-kill strategy against the banana weevil, Cosmopolites sordidus. Entomol. Exp. Appl. 2014, 151, 75-85. [CrossRef]

175. Tinzaara, W.; Emudong, P.; Nankinga, C.; Tushemereirwe, W.; Kagezi, G.; Gold, C.S.; Dicke, M.; Van Huis, A.; Karamura, E. Enhancing dissemination of Beauveria bassiana with host plant base incision trap for the management of the banana weevil Cosmopolites sordidus. Afr. J. Agric. Res. 2015, 10, 3878-3884. [CrossRef]

176. Yasuda, K. Auto-infection system for the sweetpotato weevil, Cylas formicarius (Fabricius) (Coleoptera: Curculionidae) with entomopathogenic fungi, Beauveria bassiana using a modified sex pheromone trap in the field. Appl. Entomol. Zool. 1999, 34, 501-505. [CrossRef]

177. El-Sufty, R.; Al Bgham, S.; Al-Awash, S.; Shahdad, A.; Al Bathra, A. A Trap for auto-dissemination of the entomopathogenic fungus Beauveria bassiana by red palm weevil adults in date palm plantations. Egypt J. Biol. Pest Control 2011, 21, 271-276.

178. Sewify, G.H.; Belal, M.H.; Saeed, M.Q. Using pheromone mass-trapping and the entomopathogenic fungus Beauveria bassiana in IPM programs for controlling the red palm weevil, Rhynchophorus ferrugineus Olivier (Coleoptera: Rhynchophoridae). Egypt J. Biol. Pest Control 2014, 24, 197-202.

179. Dembilio, Ó.; Moya, P.; Vacas, S.; Ortega-Garcia, L.; Quesada-Moraga, E.; Jaques, J.A.; Navarro-Llopis, V. Development of an attract-and-infect system to control Rhynchophorus ferrugineus with the entomopathogenic fungus Beauveria bassiana. Pest. Manag. Sci. 2018, 74, 1861-1869. [CrossRef]

180. El-Sufty, R.; Al Bgham, S.; Al-Awash, S.; Shahdad, A.; Al Bathra, A. A study on a trap for autodissemination of the entomopathogenic fungus Beauveria bassiana by red palm weevil adults in date palm plantations. J. Basic. Appl. Mycol. 2010, 1, 61-65.

181. Landolt, P.J. Sex attractant and aggregation pheromones of male phytophagous insects. Am. Entomol. 1997, 43, 12-22. [CrossRef]

182. Uemura-Lima, D.H.; Ventura, M.U.; Mikami, A.Y.; da Silva, F.C.; Morales, L. Responses of coffee berry borer, Hypothenemus hampei (Ferrari) (Coleoptera: Scolytidae), to vertical distribution of methanol:ethanol traps. Neotrop. Entomol. 2010, 39, 930-933. [CrossRef]

183. Pereira, A.E.; Vilela, E.F.; Tinoco, R.S.; de Lima, J.O.G.; Fantine, A.K.; Morais, E.G.F.; França, C.F.M. Correlation between numbers captured and infestation levels of the coffee berry-borer, Hypothenemus hampei: A preliminary basis for an action threshold using baited traps. Int. J. Pest Manag. 2012, 58, 183-190. [CrossRef]

184. Sewify, G.H.; Belal, M.H.; Qaed, M.S. Food-baited aggregation pheromone traps for management of the red palm weevil Rhynchophorus ferrugineus Olivier (Coleoptera: Curculionidae). Egypt J. Biol. Pest Control 2014, 24, 431-436.

185. Vacas, S.; Abad-Payá, M.; Primo, J.; Navarro-Llopis, V. Identification of pheromone synergists for Rhynchophorus ferrugineus trapping systems from Phoenix canariensis palm volatiles. J. Agric. Food Chem. 2014, 62, 6053-6064. [CrossRef]

186. Dotaona, R.; Wilson, B.A.L.; Stevens, M.M.; Holloway, J.; Ash, G.J. Chronic effects and horizontal transmission of Metarhizium anisopliae strain QS155 infection in the sweetpotato weevil, Cylas formicarius (Coleoptera: Brentidae). Biol. Control 2017, 114, 24-29. [CrossRef]

187. Schoeman, P.S.; Schoeman, M.H. Transmission of Beauveria bassiana from infected to uninfected adults of the banana weevil Cosmopolites sordidus (Coleoptera: Curculionidae). Afr. Plant Prot. 1999, 5, 53-54.

188. Llácer, E.; Santiago-Álvarez, C.; Jacas, J.A. Could sterile males be used to vector a microbiological control agent? The case of Rhynchophorus ferrugineus and Beauveria bassiana. Bull. Entomol. Res. 2013, 103, 241-250. [CrossRef] 
189. Bojke, A.; Tkaczuk, C.; Stepnowski, P.; Golebiowski, M. Comparison of volatile compounds released by entomopathogenic fungi. Microbiol. Res. 2018, 214, 129-136. [CrossRef]

190. Herrera, J.M.; Pizzolitto, R.P.; Zunino, M.P.; Dambolena, J.S.; Zygadlo, J.A. Effect of fungal volatile organic compounds on a fungus and an insect that damage stored maize. J. Stored Prod. Res. 2015, 62, 74-80. [CrossRef]

191. Dotaona, R.; Wilson, B.A.L.; Ash, G.J.; Holloway, J.; Stevens, M.M. Sweetpotato weevil, Cylas formicarius (Fab.) (Coleoptera: Brentidae) avoids its host plant when a virulent Metarhizium anisopliae isolate is present. J. Invertebr. Pathol. 2017, 148, 67-72. [CrossRef]

192. Leng, P.H.; Reddy, G.V.P. Bioactivity of selected eco-friendly pesticides against Cylas formicarius (Coleoptera: Brentidae). Fla. Entomol. 2012, 95, 1040-1047. [CrossRef]

193. Akello, J.; Dubois, T.; Coyne, D.; Kyamanywa, S. Effect of endophytic Beauveria bassiana on populations of the banana weevil, Cosmopolites sordidus, and their damage in tissue-cultured banana plants. Entomol. Exp. Appl. 2008, 129, 157-165. [CrossRef]

194. Akello, J.; Dubois, T.; Coyne, D.; Kyamanywa, S. Endophytic Beauveria bassiana in banana (Musa spp.) reduces banana weevil (Cosmopolites sordidus) fitness and damage. Crop Prot. 2008, 27, 1437-1441. [CrossRef]

195. Arab, Y.A.; El-Deeb, H.M. The use of endophyte Beauveria bassiana for bio-protection of date palm seedlings against red palm weevil and rhizoctonia root-rot disease. Sci. J. King Faisal Univ. 2012, 13, 91-101.

196. Villacarlos, L.T.; Granados-Polo, M.F.U. Potential of Metarhizium anisopliae for the control of the sweetpotato weevil, Cylas formicarius (F.) (Curculionidae: Coleoptera). Philipp. J. Crop Sci. 1989, 14, 109-114.

197. El Kichaoui, A.Y.; Abu Asaker, B.A.; El-Hindi, M.W. Isolation, molecular identification and under lab evaluation of the entomopathogenic fungi $M$. anisopliae and B. bassiana against the red palm weevil R. ferrugineus in Gaza Strip. Adv. Microbiol. 2017, 7, 109-124. [CrossRef]

198. McPhie, D.; Burrack, H.J. Effects of microbial, organically acceptable, and reduced risk insecticides on Anthonomus signatus (Curculionidae: Coleoptera) in strawberries (Fragaria x ananassa). Crop Prot. 2016, 89, 255-258. [CrossRef]

199. Irulandi, S.; Aiyanathan, K.E.A.; Bhuvaneswari, S.S.B. Assessment of biopesticides and insecticide against pseudostem weevil Odoiporus longicollis Oliver in red banana. J. Biopestic. 2012, 5, 68-71.

200. Reddy, G.V.P.; Zhao, Z.H.; Humber, R.A. Laboratory and field efficacy of entomopathogenic fungi for the management of the sweetpotato weevil, Cylas formicarius (Coleoptera: Brentidae). J. Invertebr. Pathol. 2014, 122, 10-15. [CrossRef]

201. Saleem, M.A.; Qayyum, M.A.; Ali, M.; Amin, M.; Tayyab, M.; Maqsood, S. Effect of sub-lethal doses of Beauveria bassiana and nitenpyram on the development of red palm weevil, Rhynchophorus ferrugineus (Olivier). Pak. J. Zool. 2019, 51, 559-565. [CrossRef]

202. Malik, M.A.; Manzoor, M.; Ali, H.; Muhammad, A.; ul Islam, S.; Qasim, M.; Ahmad, N.; Idrees, A.; Muhammad, A.; Saqib, H.S.A. Evaluation of imidacloprid and entomopathogenic fungi, Beauveria bassiana against the red palm weevil Rhynchophorus ferrugineus (Coleoptera: Curculionidae). J. Entomol. Zool. Stud. 2016, 4, 262-268.

203. Alston, D.G.; Rangel, D.E.N.; Lacey, L.A.; Golez, H.G.; Kim, J.J.; Roberts, D.W. Evaluation of novel fungal and nematode isolates for control of Conotrachelus nenuphar (Coleoptera: Curculionidae) larvae. Biol. Control 2005, 35, 163-171. [CrossRef]

204. Harrison, R.D.; Gardner, W.A.; Kinard, D.J. Relative susceptibility of pecan weevil fourth instars and adults to selected isolates of Beauveria bassiana. Biol. Control 1993, 3, 34-38. [CrossRef]

205. Cheng, Y.Q.; Liu, T.; Zhao, Y.X.; Geng, W.T.; Chen, L.T.; Liu, J.F. Evaluation of pathogenicity of the fungi Metarhizium anisopliae and Beauveria bassiana in hazelnut weevil (Curculio nucum L., Coleoptera, Curculionidae) larvae. Indian J. Microbiol. 2016, 56, 405-410. [CrossRef] [PubMed]

206. Ihara, F.; Toyama, M.; Sato, T. Pathogenicity of Metarhizium anisopliae to the chestnut weevil larvae under laboratory and field conditions. Appl. Entomol. Zool. 2003, 38, 461-465. [CrossRef]

207. Ihara, F.; Toyama, M.; Higaki, M.; Mishwo, K.; Yaginuma, K. Comparison of pathogenicities of Beauveria bassiana and Metarhizium anisopliae to chestnut pests. Appl. Entomol. Zool. 2009, 44, 127-132. [CrossRef]

208. Tedders, W.L.; Weaver, D.J.; Wehunt, E.J. Pecan weevil: Suppression of larvae with the fungi Metarhizium anisopliae and Beauveria bassiana and the nematode Neoaplectana dutkyi. J. Econ. Entomol. 1973, 66, 723-725. [CrossRef] 
209. Tedders, W.L.; Weaver, D.J.; Wehunt, E.J.; Gentry, C.R. Bioassay of Metarhizium anisopliae, Beauveria bassiana, and Neoaplectana carpocapsae against larvae of the plum curculio, Conotrachelus nenuphar (Herbst) (Coleoptera: Curculionidae). Environ. Entomol. 1982, 11, 901-904. [CrossRef]

210. Batalla-Carrera, L.; Morton, A.; Santamaria, S.; Garcia-del-Pino, F. Isolation and virulence of entomopathogenic fungi against larvae of hazelnut weevil Curculio nucum (Coleoptera, Curculionidae) and the effects of combining Metarhizium anisopliae with entomopathogenic nematodes in the laboratory. Biocontrol Sci. Technol. 2013, 23, 101-125. [CrossRef]

211. Champlin, F.R.; Cheung, P.Y.K.; Pekrul, S.; Smith, R.J.; Burton, R.L.; Grula, E.A. Virulence of Beauveria bassiana mutants for the pecan weevil. J. Econ. Entomol. 1981, 74, 617-621. [CrossRef]

212. Gottwald, T.R.; Tedders, W.L. Colonization, transmission, and longevity of Beauveria bassiana and Metarhizium anisopliae (Deuteromycotina: Hypomycetes) on pecan weevil larvae (Coleoptera: Curculionidae) in the soil. Environ. Entomol. 1984, 13, 557-560. [CrossRef]

213. Torrini, G.; Benvenuti, C.; Binazzi, F.; Marianelli, L.; Paoli, F.; Peverieri, G.S.; Roversi, P.F. Entomopathogenic fungi and nematodes against larvae of the chestnut weevil, Curculio elephas (Coleoptera: Curculionidae): A laboratory evaluation. Int. J. Pest Manag. 2018, 64, 287-293. [CrossRef]

214. Shapiro-Ilan, D.I.; Gardner, W.A.; Fuxa, J.R.; Wood, B.W.; Nguyen, K.B.; Adams, B.J.; Humber, R.A.; Hall, M.J. Survey of entomopathogenic nematodes and fungi endemic to pecan orchards of the Southeastern United States and their virulence to the pecan weevil (Coleoptera: Curculionidae). Environ. Entomol. 2003, 32, 187-195. [CrossRef]

215. Shapiro-Ilan, D.I.; Brown, I. Earthworms as phoretic hosts for Steinernema carpocapsae and Beauveria bassiana: Implications for enhanced biological control. Biol. Control 2013, 66, 41-48. [CrossRef]

216. Gottwald, T.R.; Tedders, W.L. Suppression of pecan weevil (Coleoptera: Curculionidae) populations with entomopathogenic fungi. Environ. Entomol. 1983, 12, 471-474. [CrossRef]

217. Shapiro-Ilan, D.I.; Cottrell, T.E.; Gardner, W.A.; Leland, J.; Behles, R.W. Laboratory mortality and mycosis of adult Curculio caryae (Coleoptera: Curculionidae) following application of Metarhizium anisopliae in the laboratory or field. J. Entomol. Sci. 2009, 44, 24-36. [CrossRef]

218. Shapiro-Ilan, D.I.; Gardner, W.A.; Wells, L.; Wood, B.W. Cumulative impact of a clover cover crop on the persistence and efficacy of Beauveria bassiana in suppressing the pecan weevil (Coleoptera: Curculionidae). Environ. Entomol. 2012, 41, 298-307. [CrossRef] [PubMed]

219. Sarraquigne, J.P.; Couturié, E.; Fernandez, M.M. Integrated control of hazelnut weevil (Curculio nucum): An evaluation of entomopathogenic nematodes and parasitic fungi. Acta Hortic. 2009, 845, 555-560. [CrossRef]

220. Pereault, R.J.; Whalon, M.E.; Alston, D.G. Field efficacy of entomopathogenic fungi and nematodes targeting caged last-instar plum curculio (Coleoptera: Curculionidae) in Michigan cherry and apple orchards. Environ. Entomol. 2009, 38, 1126-1134. [CrossRef]

221. Shapiro-Ilan, D.I.; Cottrell, T.E.; Gardner, W.A. Trunk perimeter applications of Beauveria bassiana to suppress adult Curculio caryae (Coleoptera: Curculionidae). J. Entomol. Sci. 2004, 39, 337-349. [CrossRef]

222. Shapiro-Ilan, D.I.; Mizell, R.F. An insect pupal cell with antimicrobial properties that suppress an entomopathogenic fungus. J. Invertebr. Pathol. 2015, 124, 114-116. [CrossRef]

223. Shapiro-Ilan, D.I.; Gardner, W.A.; Cottrell, T.E.; Behle, R.W.; Wood, B.W. Comparison of application methods for suppressing the pecan weevil (Coleoptera: Curculionidae) with Beauveria bassiana under field conditions. Environ. Entomol. 2008, 37, 162-171. [CrossRef]

224. Shapiro-Ilan, D.I.; Cottrell, T.E.; Gardner, W.A.; Behle, R.W.; Ree, B.; Harris, M.K. Efficacy of entomopathogenic fungi in suppressing pecan weevil, Curculio caryae (Coleoptera: Curculionidae), in commercial pecan orchards. Southwest Entomol. 2009, 34, 111-120. [CrossRef]

225. Shapiro-Ilan, D.I.; Gardner, W.A.; Wells, L.; Cottrell, T.E.; Behle, R.W.; Wood, B.W. Effects of entomopathogenic fungus species, and impact of fertilizers, on biological control of pecan weevil (Coleoptera: Curculionidae). Environ. Entomol. 2013, 42, 253-261. [CrossRef] [PubMed]

226. Shapiro-Ilan, D.I.; Jackson, M.; Reilly, C.C.; Hotchkiss, M.W. Effects of combining an entomopathogenic fungi or bacterium with entomopathogenic nematodes on mortality of Curculio caryae (Coleoptera: Curculionidae). Biol. Control 2004, 30, 119-126. [CrossRef] 
227. Asan, C.; Hazir, S.; Cimen, H.; Ulug, D.; Taylor, J.; Butt, T.; Karagoz, M. An innovative strategy for control of the chestnut weevil Curculio elephas (Coleoptera: Curculionidae) using Metarhizium brunneum. Crop Prot. 2017, 102, 147-153. [CrossRef]

228. Shapiro-Ilan, D.I.; Cottrell, T.E.; Bock, C.; Mai, K.; Boykin, D.; Wells, L.; Hudson, W.G.; Mizell, R.F. Control of pecan weevil with microbial biopesticides. Environ. Entomol. 2017, 46, 1299-1304. [CrossRef]

229. Shapiro-Ilan, D.I.; Cottrell, T.E.; Wood, B.W. Effects of combining microbial and chemical insecticides on mortality of the pecan weevil (Coleoptera: Curculionidae). J. Econ. Entomol. 2011, 104, 14-20. [CrossRef]

230. Brito, E.S.; de Paula, A.R.; Vieira, L.P.; Dolinski, C.; Samuels, R.I. Combining vegetable oil and sub-lethal concentrations of imidacloprid with Beauveria bassiana and Metarhizium anisopliae against adult guava weevil Conotrachelus psidii (Coleoptera: Curculionidae). Biocontrol Sci. Technol. 2008, 18, 665-673. [CrossRef]

231. Sepulveda, M.; Vargas, M.; Gerding, M.; Ceballos, R.; Oyarzua, P. Molecular, morphological and pathogenic characterization of six strains of Metarhizium spp. (Deuteromycotina: Hyphomycetes) for the control of Aegorhinus superciliosus (Coleoptera: Curculionidae). Chil. J. Agric. Res. 2016, 76, 77-83. [CrossRef]

232. McCoy, C.W.; Boucias, D.G. Selection of Beauveria bassiana pathotypes as potential microbial control agents of soil-inhabiting citrus weevils. Mem. Inst. Oswaldo Cruz 1989, 84, 75-80. [CrossRef]

233. Moorhouse, E.R.; Gillespie, A.T.; Charnley, A.K. Laboratory selection of Metarhizium spp. isolates for control of vine weevil larvae (Otiorhynchus sulcatus). J. Invertebr. Pathol. 1993, 62, 15-21. [CrossRef]

234. Moorhouse, E.R.; Gillespie, A.T.; Charnley, A.K. The influence of temperature on the susceptibility of vine weevil, Otiorhynchus sulcatus (Fabricius) (Coleoptera: Curculionidae), larvae to Metarhizium anisopliae (Deuteromycotina: Hyphomycetes). Ann. Appl. Biol. 1994, 124, 185-193. [CrossRef]

235. Bruck, D.J. Natural occurrence of entomopathogens in pacific northwest nursery soils and their virulence to the black vine weevil, Otiorhynchus sulcatus (F.) (Coleoptera: Curculionidae). Environ. Entomol. 2004, 33, 1335-1343. [CrossRef]

236. Hirsch, J.; Reineke, A. Efficiency of commercial entomopathogenic fungal species against different members of the genus Otiorhynchus (Coleoptera: Curculionidae) under laboratory and semi-field conditions. J. Plant Dis. Prot. 2014, 121, 211-218. [CrossRef]

237. Klingen, I.; Westrum, K.; Meyling, N.V. Effect of Norwegian entomopathogenic fungal isolates against Otiorhynchus sulcatus larvae at low temperatures and persistence in strawberry rhizospheres. Biol. Control 2015, 81, 1-7. [CrossRef]

238. Pope, T.W.; Hough, G.; Arbona, C.; Roberts, H.; Bennison, J.; Buxton, J.; Prince, G.; Chandler, D. Investigating the potential of an autodissemination system for managing populations of vine weevil, Otiorhynchus sulcatus (Coleoptera: Curculionidae) with entomopathogenic fungi. J. Invertebr. Pathol. 2018, 154, 79-84. [CrossRef] [PubMed]

239. Morera-Margarit, P.; Karley, A.J.; Mitchell, C.; Graham, R.I.; Pope, T.W. Geographic origin may not influence vine weevil Otiorhynchus sulcatus (Fabricius) susceptibility to the entomopathogenic fungus Metarhizium brunneum (Petch). Biocontrol Sci. Technol. 2020. [CrossRef]

240. Poprawski, T.J.; Marchal, M.; Robert, P.H. Comparative susceptibility of Otiorhynchus sulcatus and Sitona lineatus (Coleoptera: Curculionidae) early stages to five entomopathogenic Hyphomycetes. Environ. Entomol. 1985, 14, 247-253. [CrossRef]

241. Soares Jr, G.G.; Marchal, M.; Ferron, P. Susceptibility of Otiorhynchus sulcatus (Coleoptera: Curculionidae) larvae to Metarhizium anisopliae and Metarhizium flavoviride (Deuteromycotina: Hyphomycetes) at two different temperatures. Environ. Entomol. 1983, 12, 1887-1891. [CrossRef]

242. Dlamini, B.E.; Malan, A.P.; Addison, P. Control of the banded fruit weevil, Phlyctinus callosus (Schonherr) (Coleoptera: Curculionidae), using entomopathogenic fungi. Afr. Entomol. 2020, 28, 106-114. [CrossRef]

243. Moorhouse, E.R.; Gillespie, A.T.; Charnley, A.K. Effect of potting media on the control of Otiorhynchus sulcatus larvae on outdoor strawberry plants using the entomogenous fungus Metarhizium anisopliae. Biol. Control 1992, 2, 238-243. [CrossRef]

244. Moorhouse, E.R.; Easterbrook, M.A.; Gillespie, A.T.; Charnley, A.K. Control of Otiorhynchus sulcatus (Fabricius) (Coleoptera: Curculionidae) larvae on a range of hardy ornamental nursery stock species using the entomogenous fungus Metarhizium anisopliae. Biocontrol Sci. Technol. 1993, 3, 63-72. [CrossRef]

245. Moorhouse, E.R.; Gillespie, A.T.; Charnley, A.K. Application of Metarhizium anisopliae (Metsch.) Sor. conidia to control Otiorhynchus sulcatus (F) (Coleoptera: Curculionidae) larvae on glasshouse pot plants. Ann. Appl. Biol. 1993, 122, 623-636. [CrossRef] 
246. Moorhouse, E.R.; Gillespie, A.T.; Charnley, A.K. The development of Otiorhynchus sulcatus (Fabricius) (Coleoptera: Curculionidae) larvae on a range of ornamental pot-plant species and the potential for control using Metarhizium anisopliae. J. Hortic. Sci. 1993, 68, 627-635. [CrossRef]

247. Moorhouse, E.R.; Gillespie, A.T.; Charnley, A.K. Selection of virulent and persistent Metarhizium anisopliae isolates to control black vine weevil (Otiorhynchus sulcatus) larvae on glasshouse Begonia. J. Invertebr. Pathol. 1993, 62, 47-52. [CrossRef]

248. Bruck, D.J. Ecology of Metarhizium anisopliae in soilless potting media and the rhizosphere: Implications for pest management. Biol. Control 2005, 32, 155-163. [CrossRef]

249. Bruck, D.J.; Donahue, K.M. Persistence of Metarhizium anisopliae incorporated into soilless potting media for control of the black vine weevil, Otiorhynchus sulcatus in container-grown ornamentals. J. Invertebr. Pathol. 2007, 95, 146-150. [CrossRef] [PubMed]

250. Noble, R.; Dobrovin-Pennington, A.; Fitzgerald, J.; Dew, K.; Wilson, C.; Ross, K.; Perkins, C. Improving biocontrol of black vine weevil (Otiorhynchus sulcatus) with entomopathogenic fungi in growing media by incorporating spent mushroom compost. Biocontrol 2018, 63, 697-706. [CrossRef]

251. Cross, J.V.; Burgess, C.M. Localised insecticide treatment for the control of vine weevil larvae (Otiorhynchus sulcatus) on field-grown strawberry. Crop Prot. 1997, 16, 565-574. [CrossRef]

252. Oddsdottir, E.S.; Eilenberg, J.; Sen, R.; Halldorsson, G. The effects of insect pathogenic soil fungi and ectomycorrhizal inoculation of birch seedlings on the survival of Otiorhynchus larvae. Agric. For. Entomol. 2010, 12, 319-324. [CrossRef]

253. Vainio, A.; Hokkanen, H.M.T. The potential of entomopathogenic fungi and nematodes against Otiorhynchus ovatus L. and O. dubius Ström (Col., Curculionidae) in the field. J. Appl. Entomol. 1993, 115, 379-387. [CrossRef]

254. Bruck, D.J. Effect of potting media components on the infectivity of Metarhizium anisopliae against the black vine weevil (Coleoptera: Curculionidae). J. Environ. Hortic. 2006, 24, 91-94. [CrossRef]

255. Bruck, D.J. Efficacy of Metarhizium anisopliae as a curative application for black vine weevil (Otiorhynchus sulcatus) infesting container-grown nursery crops. J. Environ. Hortic. 2007, 25, 150-156. [CrossRef]

256. Booth, S.R.; Shanks Jr, C.H. Potential of a dried rice/mycelium formulation of entomopathogenic fungi to suppress subterranean pests in small fruits. Biocontrol Sci. Technol. 1998, 8, 197-206. [CrossRef]

257. Booth, S.R.; Tanigoshi, L.; Dewes, I. Potential of a dried mycelium formulation of an indigenous strain of Metarhizium anisopliae against subterranean pests of cranberry. Biocontrol Sci. Technol. 2000, 10, 659-668. [CrossRef]

258. Easter-brook, M.A.; Cantwell, M.P.; Chandler, D. Control of the black vine weevil, Otiorhynchus sulcatus, with the fungus Metarhizium anisopliae. Phytoparasitica 1992, 20, S17-S19. [CrossRef]

259. Roberts, J.M.; Jahir, A.; Graham, J.; Pope, T.W. Catch me if you can: The influence of refuge/trap design, previous feeding experience, and semiochemical lures on vine weevil (Coleoptera: Curculionidae) monitoring success. Pest Manag. Sci. 2019, 76, 553-560. [CrossRef]

260. van Tol, R.W.H.M.; Elberse, I.A.M.; Bruck, D.J. Development of a refuge-kairomone device for monitoring and control of the vine weevil, Otiorhynchus sulcatus, by lure-and-kill and lure-and-infect. Crop Prot. 2020, 129, 105045. [CrossRef]

261. Rondot, Y.; Reineke, A. Association of Beauveria bassiana with grapevine plants deters adult black vine weevils, Otiorhynchus sulcatus. Biocontrol Sci. Technol. 2017, 27, 811-820. [CrossRef]

262. Kepler, R.M.; Bruck, D.J. Examination of the interaction between the black vine weevil (Coleoptera: Curculionidae) and an entomopathogenic fungus reveals a new tritrophic interaction. Environ. Entomol. 2006, 35, 1021-1029. [CrossRef]

263. Ansari, M.A.; Shah, F.A.; Butt, T.M. Combined use of entomopathogenic nematodes and Metarhizium anisopliae as a new approach for black vine weevil, Otiorhynchus sulcatus, control. Entomol. Exp. Appl. 2008, 129, 340-347. [CrossRef]

264. Ansari, M.A.; Shah, F.A.; Butt, T.M. The entomopathogenic nematode Steinernema kraussei and Metarhizium anisopliae work synergistically in controlling overwintering larvae of the black vine weevil, Otiorhynchus sulcatus, in strawberry growbags. Biocontrol Sci. Technol. 2010, 20, 99-105. [CrossRef]

265. Ansari, M.A.; Butt, T.M. Influence of the application methods and doses on the susceptibility of black vine weevil larvae Otiorhynchus sulcatus to Metarhizium anisopliae in field-grown strawberries. Biocontrol 2013, 58, 257-267. [CrossRef] 
266. Quintela, E.D.; McCoy, C.W. Pathogenicity enhancement of Metarhizium anisopliae and Beauveria bassiana to first instars of Diaprepes abbreviatus (Coleoptera: Curculionidae) with sublethal doses of imidacloprid. Environ. Entomol. 1997, 26, 1173-1182. [CrossRef]

267. Quintela, E.D.; McCoy, C.W. Conidial attachment of Metarhizium anisopliae and Beauveria bassiana to the larval cuticle of Diaprepes abbreviatus (Coleoptera: Curculionidae) treated with imidacloprid. J. Invertebr. Pathol. 1998, 72, 220-230. [CrossRef] [PubMed]

268. Quintela, E.D.; McCoy, C.W. Synergistic effect of imidacloprid and two entomopathogenic fungi on the behavior and survival of larvae of Diaprepes abbreviatus (Coleoptera: Curculionidae) in soil. J. Econ. Entomol. 1998, 91, 110-122. [CrossRef]

269. Shah, F.A.; Ansari, M.A.; Prasad, M.; Butt, T.M. Evaluation of black vine weevil (Otiorhynchus sulcatus) control strategies using Metarhizium anisopliae with sublethal doses of insecticides in disparate horticultural growing media. Biol. Control 2007, 40, 246-252. [CrossRef]

270. Shah, F.A.; Gaffney, M.; Ansari, M.A.; Prasad, M.; Butt, T.M. Neem seed cake enhances the efficacy of the insect pathogenic fungus Metarhizium anisopliae for the control of black vine weevil, Otiorhynchus sulcatus (Coleoptera: Curculionidae). Biol. Control 2008, 44, 111-115. [CrossRef]

271. Gillett-Kaufman, J.L.; Kimbrough, J.W. A modified method to visualize infection sites of spores of the entomopathogen Beauveria bassiana (Deuteromycotina: Hyphomycetes) on the exoskeleton of citrus root weevil Diaprepes abbreviatus (Coleoptera: Curculionidae) adults. Fla. Entomol. 2009, 92, 623-628.

272. Jaber, L.R.; Ownley, B.H. Can we use entomopathogenic fungi as endophytes for dual biological control of insect pests and plant pathogens? Biol. Control 2018, 116, 36-45. [CrossRef]

273. Bamisile, B.S.; Dash, C.K.; Akutse, K.S.; Keppanan, R.; Wang, L.D. Fungal endophytes: Beyond herbivore management. Front. Microbiol. 2018, 9, 544. [CrossRef]

274. Ramakuwela, T.; Hatting, J.; Bock, C.; Vega, F.E.; Wells, L.; Mbata, G.N.; Shapiro-Ilan, D.I. Establishment of Beauveria bassiana as a fungal endophyte in pecan (Carya illinoinensis) seedlings and its virulence against pecan insect pests. Biol. Control 2020, 140, 104102. [CrossRef]

275. Posada, F.; Vega, F.E. Establishment of the fungal entomopathogen Beauveria bassiana (Ascomycota: Hypocreales) as an endophyte in cocoa seedlings (Theobroma cacao). Mycologia 2005, 97, 1195-1200. [CrossRef] [PubMed]

276. Posada, F.; Aime, M.C.; Peterson, S.W.; Rehner, S.A.; Vega, F.E. Inoculation of coffee plants with the fungal entomopathogen Beauveria bassiana (Ascomycota: Hypocreales). Mycol. Res. 2007, 111, 748-757. [CrossRef] [PubMed]

277. Gómez-Vidal, S.; Lopez-Llorca, L.V.; Jansson, H.B.; Salinas, J. Endophytic colonization of date palm (Phoenix dactylifera L.) leaves by entomopathogenic fungi. Micron 2006, 37, 624-632. [CrossRef]

278. Bamisile, B.S.; Dash, C.K.; Akutse, K.S.; Qasim, M.; Aguila, L.C.R.; Wang, F.F.; Keppanan, R.; Wang, L.D. Endophytic Beauveria bassiana in foliar-treated Citrus limon plants acting as a growth suppressor to three successive generations of Diaphorina citri Kuwayama (Hemiptera: Liviidae). Insects 2019, 10, 176. [CrossRef]

279. Rondot, Y.; Reineke, A. Endophytic Beauveria bassiana in grapevine Vitis vinifera (L.) reduces infestation with piercing-sucking insects. Biol. Control 2018, 116, 82-89. [CrossRef]

280. Bing, L.A.; Lewis, L.C. Occurrence of the entomopathogen Beauveria bassiana (Balsamo) Vuillemin in different tillage regimes and in Zea mays L and virulence towards Ostrinia nubilalis (Hubner). Agric. Ecosyst. Environ. 1993, 45, 147-156. [CrossRef]

281. Oliveira, I.; Pereira, J.A.; Quesada-Moraga, E.; Lino-Neto, T.; Bento, A.; Baptista, P. Effect of soil tillage on natural occurrence of fungal entomopathogens associated to Prays oleae Bern. Sci. Hortic. 2013, 159, 190-196. [CrossRef]

282. Milner, R.J.; Samson, P.; Morton, R. Persistence of conidia of Metarhizium anisopliae in sugarcane fields: Effect of isolate and formulation on persistence over 3.5 years. Biocontrol Sci. Technol. 2003, 13, 507-516. [CrossRef]

283. Mayerhofer, J.; Enkerli, J.; Zelger, R.; Strasser, H. Biological control of the European cockchafer: Persistence of Beauveria brongniartii after long-term applications in the Euroregion Tyrol. Biocontrol 2015, 60, 617-629. [CrossRef]

284. Swiergiel, W.; Meyling, N.V.; Porcel, M.; Rämert, B. Soil application of Beauveria bassiana GHA against apple sawfly, Hoplocampa testudinea (Hymenoptera: Tenthredinidae): Field mortality and fungal persistence. Insect Sci. 2016, 23, 854-868. [CrossRef] [PubMed] 
285. Coombes, C.A.; Hill, M.P.; Moore, S.D.; Dames, J.F. Entomopathogenic fungi as control agents of Thaumatotibia leucotreta in citrus orchards: Field efficacy and persistence. Biocontrol 2016, 61, 729-739. [CrossRef]

286. Baxter, I.H.; Howard, N.; Armsworth, C.G.; Barton, L.E.E.; Jackson, C. The potential of two electrostatic powders as the basis for an auto dissemination control method of Plodia interpunctella (Hubner). J. Stored Prod. Res. 2008, 44, 152-161. [CrossRef]

287. Athanassiou, C.G.; Vassilakos, T.N.; Dutton, A.C.; Jessop, N.; Sherwood, D.; Pease, G.; Brglez, A.; Storm, C.; Trdan, S. Combining electrostatic powder with an insecticide: Effect on stored-product beetles and on the commodity. Pest Manag. Sci. 2016, 72, 2208-2217. [CrossRef] [PubMed]

288. Athanassiou, C.G.; Rumbos, C.I.; Sakka, M.; Potin, O.; Storm, C.; Dillon, A.B. Delivering Beauveria bassiana with electrostatic powder for the control of stored-product beetles. Pest Manag. Sci. 2017, 73, 1725-1736. [CrossRef] [PubMed]

289. Meikle, W.G.; Mercadier, G.; Holst, N.; Nansen, C.; Girod, V. Duration and spread of an entomopathogenic fungus, Beauveria bassiana (Deuteromycota: Hyphomycetes), used to treat varroa mites (Acari: Varroidae) in honey bee (Hymenoptera: Apidae) hives. J. Econ. Entomol. 2007, 100, 1-10. [CrossRef]

290. Andriessen, R.; Snetselaar, J.; Suer, R.A.; Osinga, A.J.; Deschietere, J.; Lyimo, I.N.; Mnyone, L.L.; Brooke, B.D.; Ranson, H.; Knols, B.G.J.; et al. Electrostatic coating enhances bioavailability of insecticides and breaks pyrethroid resistance in mosquitoes. Proc. Natl. Acad. Sci. USA 2015, 112, 12081-12086. [CrossRef]

291. Mazza, G.; Inghilesi, A.F.; Stasolla, G.; Cini, A.; Cervo, R.; Benvenuti, C.; Francardi, V.; Cristofaro, M.; Arnone, S.; Roversi, P.F. Sterile Rhynchophorus ferrugineus males efficiently impair reproduction while maintaining their sexual competitiveness in a social context. J. Pest Sci. 2016, 89, 459-468. [CrossRef]

292. Sookar, P.; Alleck, M.; Ahseek, N.; Bhagwant, S. Sterile male peach fruit flies, Bactrocera zonata (Saunders) (Diptera: Tephritidae), as a potential vector of the entomopathogen Beauveria bassiana (Balsamo) Vuillemin in a SIT programme. Afr. Entomol. 2014, 22, 488-498. [CrossRef]

293. Jaronski, S.T. Ecological factors in the inundative use of fungal entomopathogens. Biocontrol 2010, 55, 159-185. [CrossRef]

294. Hedimbi, M.; Kaaya, G.P.; Singh, S.; Chimwamurombe, P.M.; Gindin, G.; Glazer, I.; Samish, M. Protection of Metarhizium anisopliae conidia from ultra-violet radiation and their pathogenicity to Rhipicephalus evertsi evertsi ticks. Exp. Appl. Acarol. 2008, 46, 149-156. [CrossRef] [PubMed]

295. de Oliveira, D.G.P.; Lopes, R.B.; Rezende, J.M.; Delalibera, I. Increased tolerance of Beauveria bassiana and Metarhizium anisopliae conidia to high temperature provided by oil-based formulations. J. Invertebr. Pathol. 2018, 151, 151-157. [CrossRef]

296. Rangel, D.E.N.; Braga, G.U.L.; Anderson, A.J.; Roberts, D.W. Variability in conidial thermotolerance of Metarhizium anisopliae isolates from different geographic origins. J. Invertebr. Pathol. 2005, 88, 116-125. [CrossRef] [PubMed]

297. Fernandes, È.K.K.; Rangel, D.E.N.; Moraes, Á.M.L.; Bittencourt, V.R.E.P.; Roberts, D.W. Variability in tolerance to UV-B radiation among Beauveria spp. isolates. J. Invertebr. Pathol. 2007, 96, 237-243. [CrossRef] [PubMed]

298. Rangel, D.E.N.; Braga, G.U.L.; Fernandes, Ė.K.K.; Keyser, C.A.; Hallsworth, J.E.; Roberts, D.W. Stress tolerance and virulence of insect-pathogenic fungi are determined by environmental conditions during conidial formation. Curr. Genet. 2015, 61, 383-404. [CrossRef] [PubMed]

299. Rangel, D.E.N.; Roberts, D.W. Possible source of the high UV-B and heat tolerance of Metarhizium acridum (isolate ARSEF 324). J. Invertebr. Pathol. 2018, 157, 32-35. [CrossRef] [PubMed]

300. Ekobu, M.; Solera, M.; Kyamanywa, S.; Mwanga, R.O.M.; Odongo, B.; Ghislain, M.; Moar, W.J. Toxicity of seven Bacillus thuringiensis cry proteins against Cylas puncticollis and Cylas brunneus (Coleoptera: Brentidae) using a novel artificial diet. J. Econ. Entomol. 2010, 103, 1493-1502. [CrossRef]

301. Mahmoud, S.B.; Ramos, J.E.; Shatters, R.G., Jr.; Hall, D.G.; Lapointe, S.L.; Niedz, R.P.; Rougé, P.; Cave, R.D.; Borovsky, D. Expression of Bacillus thuringiensis cytolytic toxin (Cyt2Ca1) in citrus roots to control Diaprepes abbreviatus larvae. Pestic. Biochem. Phys. 2017, 136,1-11. [CrossRef]

302. Anbesse, S.A.; Adge, B.J.; Gebru, W.M. Laboratory screening for virulent entomopathogenic nematodes (Heterorhabditis bacteriophora and Steinernema yirgalemense) and fungi (Metarhizium anisopliae and Beauveria bassiana) and assessment of possible synergistic effects of combined use against grubs of the barley chafer Coptognathus curtipennis. Nematology 2008, 10, 701-709.

303. Meyling, N.V.; Pell, J.K. Detection and avoidance of an entomopathogenic fungus by a generalist insect predator. Ecol. Entomol. 2006, 31, 162-171. [CrossRef] 
304. de Oliveira, F.Q.; Batista, J.D.; Malaquias, J.B.; de Brito, C.H.; Dos Santos, E.P. Susceptibility of the predator Euborellia annulipes (Dermaptera: Anisolabididae) to mycoinsecticides. Rev. Colomb. Entomol. 2011, 37, 234-237.

305. Cottrell, T.E.; Shapiro-Ilan, D.I. Susceptibility of endemic and exotic North American ladybirds (Coleoptera: Coccinellidae) to endemic fungal entomopathogens. Eur. J. Entomol. 2008, 105, 455-460. [CrossRef]

306. Zhu, H.; Kim, J.J. Target-oriented dissemination of Beauveria bassiana conidia by the predators, Harmonia axyridis (Coleoptera: Coccinellidae) and Chrysoperla carnea (Neuroptera: Chrysopidae) for biocontrol of Myzus persicae. Biocontrol Sci. Technol. 2012, 22, 393-406. [CrossRef]

307. Cottrell, T.E.; Shapiro-Ilan, D.I. Susceptibility of a native and an exotic lady beetle (Coleoptera: Coccinellidae) to Beauveria bassiana. J. Invertebr. Pathol. 2003, 84, 137-144. [CrossRef]

308. de la Rosa, W.; Segura, H.R.; Barrera, J.F.; Williams, T. Laboratory evaluation of the impact of entomopathogenic fungi on Prorops nasuta (Hymenoptera: Bethylidae), a parasitoid of the coffee berry borer. Environ. Entomol. 2000, 29, 126-131. [CrossRef]

309. Potrich, M.; Alves, L.F.A.; Lozano, E.; Roman, J.C.; Pietrowski, V.; Neves, P.M.O.J. Interactions between Beauveria bassiana and Trichogramma pretiosum under laboratory conditions. Entomol. Exp. Appl. 2015, 154, 213-221. [CrossRef]

310. Potrich, M.; Alves, L.F.A.; Lozano, E.R.; Bonini, A.K.; Neves, P.M.O.J. Potential side effects of the entomopathogenic fungus Metarhizium anisopliae on the egg parasitoid Trichogramma pretiosum (Hymenoptera: Trichogrammatidae) under controlled conditions. J. Econ. Entomol. 2017, 110, 2318-2324. [CrossRef]

311. Potrich, M.; Alves, L.F.A.; Haas, J.; da Silva, E.R.L.; Daros, A.; Pietrowski, V.; Neves, P.M.O.J. Selectivity of Beauveria bassiana and Metarhizium anisopliae to Trichogramma pretiosum Riley (Hymenoptera: Trichogrammatidae). Neotrop. Entomol. 2009, 38, 822-826. [CrossRef]

312. Castillo, A.; Gómez, J.; Infante, F.; Vega, F.E. Susceptibility of the parasitoid Phymastichus coffea LaSalle (Hymenoptera: Eulophidae) to Beauveria bassiana under laboratory conditions. Neotrop. Entomol. 2009, 38, 665-670. [CrossRef]

313. De la Rosa, W.; Godinez, J.L.; Alatorre, R.; Trujillo, J. Susceptibility of the parasitoid Cephalonomia stephanoderis to Beauveria bassiana and Metarhizium anisopliae strains. Southwest Entomol. 1997, 22, 233-242.

314. Khun, K.K.; Ash, G.J.; Stevens, M.M.; Huwer, R.K.; Wilson, B.A.L. Compatibility of Metarhizium anisopliae and Beauveria bassiana with insecticides and fungicides used in macadamia production in Australia. Pest Manag. Sci. 2020. [CrossRef] [PubMed]

(C) 2020 by the authors. Licensee MDPI, Basel, Switzerland. This article is an open access article distributed under the terms and conditions of the Creative Commons Attribution (CC BY) license (http://creativecommons.org/licenses/by/4.0/). 